Review

\title{
Eriophyid Mites in Classical Biological Control of Weeds: Progress and Challenges
}

\author{
Francesca Marini ${ }^{1, *(\mathbb{D})}$, Philip Weyl ${ }^{2}$, Biljana Vidović ${ }^{3}$, Radmila Petanović ${ }^{3,4}{ }^{\text {, Jeffrey Littlefield }}{ }^{5}$,

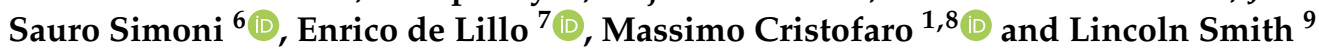

1 Biotechnology and Biological Control Agency (BBCA), via Angelo Signorelli 105, 00123 Rome, Italy; massimo.cristofaro.cas@enea.it

2 CABI, Rue des Grillons 1, 2800 Delémont, Switzerland; P.Weyl@cabi.org

3 Department of Entomology and Agricultural Zoology, Faculty of Agriculture, University of Belgrade, Nemanjina 6, 11080 Belgrade, Serbia; magud@agrif.bg.ac.rs (B.V.); rpetanov@agrif.bg.ac.rs (R.P.)

4 Serbian Academy of Sciences and Arts, Knez Mihailova 35, 11000 Belgrade, Serbia

5 Department of Land Resources and Environmental Sciences, Montana State University, Bozeman, MT 59717, USA; jeffreyl@montana.edu

6 CREA Research Centre for Plant Protection and Certification, via di Lanciola 12a, 50125 Firenze, Italy; sauro.simoni@crea.gov.it

7 Department of Plant, Soil and Food Sciences, University of Bari Aldo Moro, via Amendola 165/A, 70126 Bari, Italy; enrico.delillo@uniba.it

8 ENEA Casaccia, SSPT-BIOAG-PROBIO, via Anguillarese 301, 00123 Rome, Italy

9 USDA-ARS Western Regional Research Center, 800 Buchanan Street, Albany, CA 94710, USA; link.smith@usda.gov

* Correspondence: fra.rini.bbca@gmail.com

check for updates

Citation: Marini, F.; Weyl, P.; Vidović, B.; Petanović, R.; Littlefield, J.; Simoni, S.; de Lillo, E.; Cristofaro, M.; Smith, L. Eriophyid Mites in Classical Biological Control of Weeds: Progress and Challenges. Insects 2021, 12, 513. https://doi.org/10.3390/insects12060513

Academic Editor: Koichi Goka

Received: 9 April 2021

Accepted: 31 May 2021

Published: 1 June 2021

Publisher's Note: MDPI stays neutral with regard to jurisdictional claims in published maps and institutional affiliations.

Copyright: (c) 2021 by the authors. Licensee MDPI, Basel, Switzerland. This article is an open access article distributed under the terms and conditions of the Creative Commons Attribution (CC BY) license (https:// creativecommons.org/licenses/by/ $4.0 /)$.
Simple Summary: Eriophyid mites are tiny creatures, no bigger than a speck of dust. All species feed on plants and some can cause considerable damage. These mites have an intimate relationship with the plants that they live on, and most of the known species have been collected only from a single plant species, which suggests they are very specific to their host. They reproduce extremely quickly and can build up populations of millions, if not billions, of individuals within a single season. In recent years, research to evaluate their potential for the biological control of invasive plants has increased. Working with these minuscule herbivores poses challenges and offers opportunities for researchers. We review the most updated information in the context of weed biocontrol, giving current information on the challenges already faced and possible opportunities and solutions. We cover topics on taxonomy, evaluation of safety as biological control agents, impact and efficacy on the targeted plant species, and release and post-release monitoring. By offering the lessons learned from past research in a single updated document, our goal is to equip researchers with a valuable tool to help deal with the challenges and opportunities offered by eriophyid mites for the management of invasive plants.

Abstract: A classical biological control agent is an exotic host-specific natural enemy, which is intentionally introduced to obtain long-term control of an alien invasive species. Among the arthropods considered for this role, eriophyid mites are likely to possess the main attributes required: host specificity, efficacy, and long-lasting effects. However, so far, only a few species have been approved for release. Due to their microscopic size and the general lack of knowledge regarding their biology and behavior, working with eriophyids is particularly challenging. Furthermore, mites disperse in wind, and little is known about biotic and abiotic constraints to their population growth. All these aspects pose challenges that, if not properly dealt with, can make it particularly difficult to evaluate eriophyids as prospective biological control agents and jeopardize the general success of control programs. We identified some of the critical aspects of working with eriophyids in classical biological control of weeds and focused on how they have been or may be addressed. In particular, we analyzed the importance of accurate mite identification, the difficulties faced in the evaluation of their host specificity, risk assessment of nontarget species, their impact on the weed, and the final steps of mite release and post-release monitoring. 
Keywords: Eriophyidae; invasive alien plants; taxonomy; host plant specificity; risk assessment; impact; release; post-release monitoring

\section{Introduction}

Over past decades, international trade and travel has increased exponentially, and with that also the spread of alien species [1]. Invasive plants (hereafter called weeds) can be defined as those species that are not native (i.e., alien) to the ecosystem under consideration, and that cause or are likely to cause economic or environmental harm or harm to human, animal, or plant health [2]. Invasive weeds cost billions of dollars annually in economic costs in addition to damages to ecosystem services and loss of biodiversity [3-6]. Conventional control strategies, including mechanical (e.g., mulching, tillage) and chemical (i.e., herbicides) methods, have long been used [7]; however, they are most cost-effective for intensively managed agroecosystems and sustainability should not be taken for granted [8,9]. Such methods are less practical and cost-effective to control invasive weeds on rangeland, forests and aquatic ecosystems, where there is growing interest in alternative strategies such as biological control [10].

Classical biological control consists of the importation and release of exotic host-specific natural enemies (biological control agents) to help reduce the density of the target weed and provide long-term control [11,12]. Many successes are reported in literature ([10,13-16] and references therein), which show clearly that this approach can be a cost-effective, environmentally benign and sustainable control method for invasive alien species [17-19].

Eriophyid mites (Eriophyidae) are among the smallest arthropods known (body length around $200 \mu \mathrm{m}$ ), which makes them difficult to study [20]. About 4800 species have been recognized, some of which are significant pests of agronomic plants [21], and many others (about $80 \%$ of those currently known) have been found in association with only one host plant [22], which implies that some species might be suitable to use as biological control agents [23]. Recently developed microscopic tools and molecular genetic methods have improved the ability of scientists to identify them, facilitating their study.

The purpose of this paper is to identify some of the critical aspects of working with eriophyid mites in classical biological control of weeds and to focus on how they have been or may be addressed. Aspects such as the importance of accurate mite identification, the challenge of evaluating host specificity, the risk assessment for nontarget species, and the impact on the weed, and the steps of mite release and post-release monitoring are discussed using pertinent examples.

\section{Classical Biological Control of Weeds Using Eriophyid Mites}

In general, a classical biological control program of weeds consists of a progression of several steps, such as literature search and field surveys, evaluation of the candidate selected, submission of a petition to obtain governmental approval for its release, release, and post-release monitoring of the agent (Figure 1) [12].

Recently, interest in the use of eriophyid mites as prospective candidates in classical biological control programs of weeds has increased, since they possess many attributes that are likely to favor them as potential biological control agents. These include an intimate and coevolved relationship with their host and high host specificity, high reproductive rates with very short generation times, dispersal by wind, and potentially high impact on target plants $[21,24]$. 


\section{Stages}

STEPS

Goals

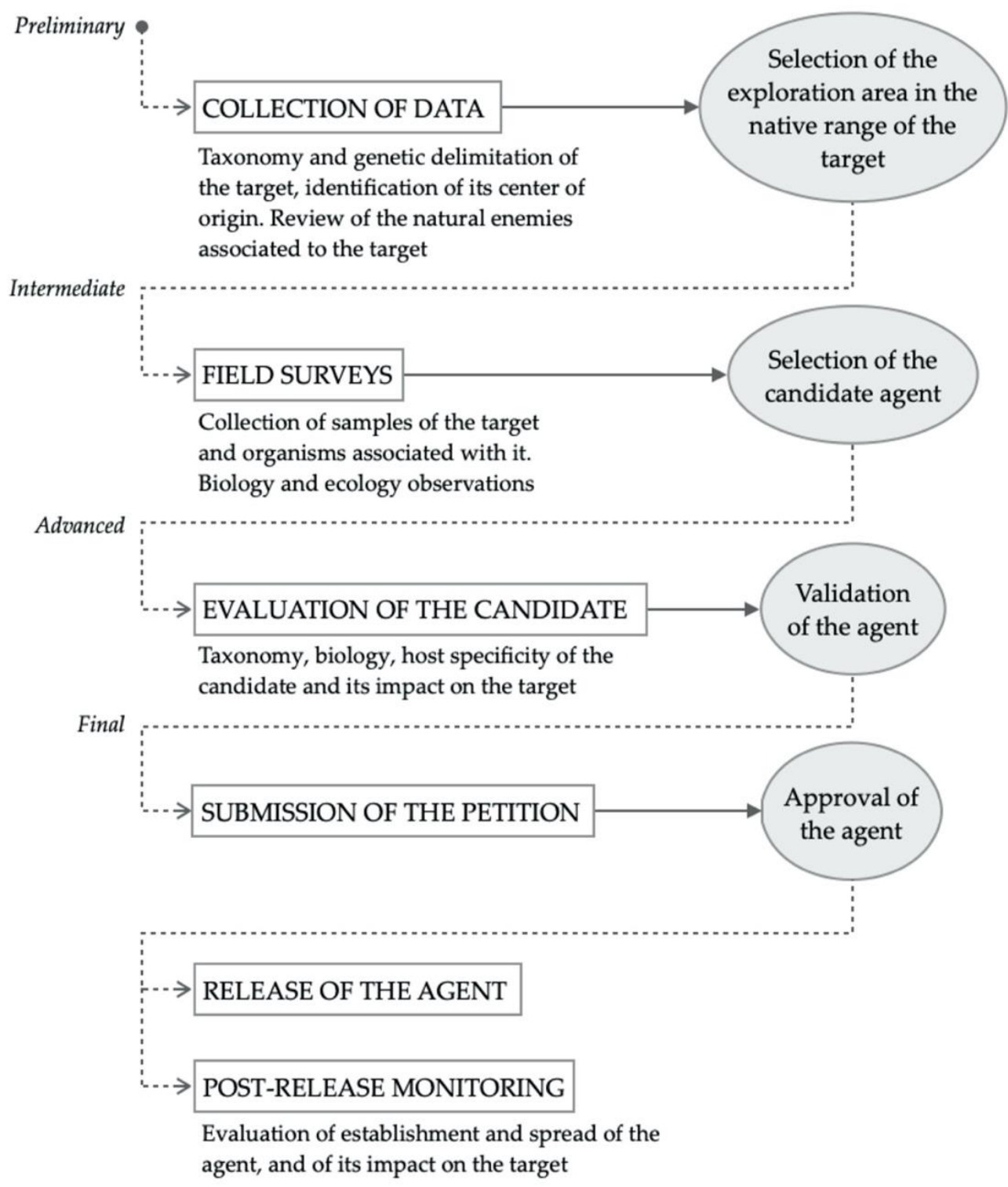

Figure 1. Main stages, key steps, and primary goals of a weed classical biological control program, including some essential activities for each step.

By feeding, eriophyid mites may induce significant disturbances in plant morphology, including stunting of leaves, reductions in internode length and in the production of fruit and seeds. In some cases, they may cause reduced growth in root, as well as in above ground biomass and reproduction [24,25]. Despite those desirable features, only few eriophyid mite species have been intentionally released. The earliest species successfully released date from the 1970s and 1980s, and they are Aceria malherbae Nuzzaci, Aceria chondrillae (Canestrini), and Aculus hyperici (Liro) ([23] and references therein). Most of the eriophyid mite species that have played some role as biological control agent thus far are actually adventive, i.e., exotic organisms which were accidentally moved, or spread naturally to another country. Some others were intentionally redistributed, and only a few of them were effectively evaluated and gained regulatory approvals for their intentional introduction (Table 1). 


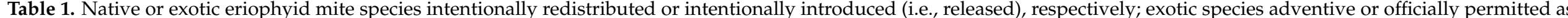

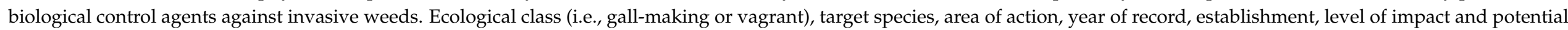

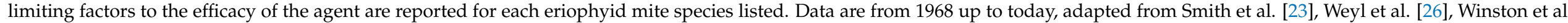
$[27,28]$, and references therein.

\begin{tabular}{|c|c|c|c|c|c|c|c|c|c|}
\hline Eriophyid Mite Species & Ecological Class & Target Species & Status & Region & Location & Year & Establishment & Impact & $\begin{array}{l}\text { Limiting } \\
\text { Factors }\end{array}$ \\
\hline \multirow{15}{*}{$\begin{array}{l}\text { Acalitus adoratus } \\
\text { Keifer }\end{array}$} & \multirow{15}{*}{$\begin{array}{l}\text { gall- } \\
\text { making }\end{array}$} & \multirow{15}{*}{$\begin{array}{l}\text { Chromolaena odorata (L.) R.M. King } \\
\text { \& H. Rob. (Asteraceae; Saimweed) }\end{array}$} & \multirow{15}{*}{ Adventive } & \multirow{11}{*}{ Asia } & Bangladesh & 2009 & Yes & Slight & - \\
\hline & & & & & China & 1991 & Yes & Slight & - \\
\hline & & & & & Indonesia & 1991 & Yes & Slight & - \\
\hline & & & & & Laos & 2009 & Yes & Slight & - \\
\hline & & & & & Malaysia & $1970 \mathrm{~s}$ & Yes & Slight & - \\
\hline & & & & & Philippines & 1987 & Yes & Slight & - \\
\hline & & & & & Singapore & 2009 & Yes & Slight & - \\
\hline & & & & & Taiwan & 1992 & Yes & Slight & - \\
\hline & & & & & Thailand & 1984 & Yes & Slight & - \\
\hline & & & & & Timor-Leste & 2003 & Yes & Slight & - \\
\hline & & & & & Vietnam & 2009 & Yes & Slight & - \\
\hline & & & & \multirow{4}{*}{ Pacific } & Guam & 2005 & Yes & Slight & - \\
\hline & & & & & $\begin{array}{l}\text { Northern } \\
\text { Marianas }\end{array}$ & 2005 & Yes & Slight & - \\
\hline & & & & & Palau & 1998 & Yes & Slight & - \\
\hline & & & & & $\begin{array}{l}\text { Papua New } \\
\text { Guinea }\end{array}$ & 2005 & Yes & Slight & - \\
\hline \multirow{2}{*}{$\begin{array}{c}\text { Aceria acroptiloni } \\
\text { Shevchenko \& Kovalev }\end{array}$} & \multirow{2}{*}{$\begin{array}{c}\text { gall- } \\
\text { making }\end{array}$} & \multirow{2}{*}{$\begin{array}{l}\text { Rhaponticum repens (L.) Hidalgo } \\
\text { (Asteraceae; Russian knapweed) }\end{array}$} & \multirow{2}{*}{$\begin{array}{l}\text { Intentionally } \\
\text { redistributed }\end{array}$} & Asia & Uzbekistan & 1997 & Yes & Heavy & - \\
\hline & & & & Eurasia & Ukraine & 1973 & Yes & Heavy & - \\
\hline \multirow{2}{*}{$\begin{array}{l}\text { Aceria angustifoliae } \\
\text { Denizhan et al. }\end{array}$} & \multirow{2}{*}{$\begin{array}{l}\text { gall- } \\
\text { making }\end{array}$} & \multirow{2}{*}{$\begin{array}{c}\text { Elaeagnus angustifolia } \mathrm{L} . \\
\text { (Elaeagnaceae; Russian olive) }\end{array}$} & \multirow{2}{*}{ Petition submitted ${ }^{1}$} & \multirow{2}{*}{ North America } & Canada & 2019 & - & - & - \\
\hline & & & & & USA & 2019 & - & - & - \\
\hline
\end{tabular}


Table 1. Cont.

\begin{tabular}{|c|c|c|c|c|c|c|c|c|c|}
\hline Eriophyid Mite Species & Ecological Class & Target Species & Status & Region & Location & Year & Establishment & Impact & $\begin{array}{l}\text { Limiting } \\
\text { Factors }\end{array}$ \\
\hline \multirow{2}{*}{$\begin{array}{l}\text { Aceria anthocoptes } \\
\quad \text { (Nalepa) }\end{array}$} & \multirow{2}{*}{ vagrant $^{2}$} & \multirow{2}{*}{$\begin{array}{l}\text { Cirsium arvense (L.) Scop. } \\
\text { (Asteraceae; Canada thistle) }\end{array}$} & \multirow{2}{*}{ Adventive } & \multirow{2}{*}{ North America } & Canada & 2011 & Yes & Unknown & - \\
\hline & & & & & USA & 1998 & Yes & Slight & - \\
\hline \multirow{4}{*}{$\begin{array}{l}\text { Aceria chondrillae } \\
\text { (Canestrini) }\end{array}$} & \multirow{4}{*}{$\begin{array}{l}\text { gall- } \\
\text { making }\end{array}$} & \multirow{4}{*}{$\begin{array}{c}\text { Chondrilla juncea } \mathrm{L} \text {. } \\
\text { (Asteraceae; rush skeletonweed) }\end{array}$} & Adventive & North America & Canada & 1993 & Yes & Slight & - \\
\hline & & & \multirow{3}{*}{$\begin{array}{l}\text { Intentionally } \\
\text { introduced }\end{array}$} & \multirow[t]{2}{*}{ Australia } & \multirow[t]{2}{*}{ Australia } & 1971 & Yes & Variable & $\begin{array}{l}\text { Specificity } \\
\text { Climate }\end{array}$ \\
\hline & & & & & & 1985 & Yes & Slight & - \\
\hline & & & & South America & Argentina & 1989 & Yes & Unknown & - \\
\hline $\begin{array}{l}\text { Aceria davidmansoni } \\
\text { Xue, Han \& Zhang }\end{array}$ & $\begin{array}{c}\text { gall- } \\
\text { making }\end{array}$ & $\begin{array}{l}\text { Ulex europaeus L. } \\
\text { (Fabaceae; gorse) }\end{array}$ & Adventive & Pacific & New Zealand & 1985 & Yes & Slight & - \\
\hline $\begin{array}{l}\text { Aceria drabae } \\
\text { (Nalepa) }\end{array}$ & $\begin{array}{l}\text { gall- } \\
\text { making }\end{array}$ & $\begin{array}{c}\text { Lepidium draba L. } \\
\text { (Brassicaceae; hoary cress) }\end{array}$ & $\begin{array}{l}\text { Intentionally } \\
\text { introduced }\end{array}$ & North America & USA & 2019 & Too early ${ }^{3}$ & Too early & - \\
\hline $\begin{array}{l}\text { Aceria genistae } \\
\text { (Nalepa) }\end{array}$ & $\begin{array}{l}\text { gall- } \\
\text { making }\end{array}$ & $\begin{array}{l}\text { Cytisus scoparius (L.) Link } \\
\text { (Fabaceae; Scotch brrom) }\end{array}$ & Adventive & North America & Canada & 2007 & Yes & Slight & - \\
\hline
\end{tabular}


Table 1. Cont.

\begin{tabular}{|c|c|c|c|c|c|c|c|c|c|}
\hline Eriophyid Mite Species & Ecological Class & Target Species & Status & Region & Location & Year & Establishment & Impact & $\begin{array}{l}\text { Limiting } \\
\text { Factors }\end{array}$ \\
\hline & & & & Australia & Australia & 2008 & Yes & Unknown & - \\
\hline & & & $\begin{array}{l}\text { Intentionally } \\
\text { introduced }\end{array}$ & Pacific & New Zealand & 2007 & Yes & Variable & $\begin{array}{l}\text { Specificity } \\
\text { Possibly } \\
\text { predation }\end{array}$ \\
\hline \multirow{7}{*}{$\begin{array}{l}\text { Aceria lantanae } \\
\quad \text { (Cook) }\end{array}$} & \multirow{7}{*}{$\begin{array}{l}\text { gall- } \\
\text { making }\end{array}$} & \multirow{7}{*}{$\begin{array}{l}\text { Lantana camara L. sens. lat. } \\
\text { (Verbenaceae; lanatana) }\end{array}$} & \multirow{4}{*}{ Adventive } & \multirow{4}{*}{ Africa } & $\begin{array}{l}\text { Kingdom of } \\
\text { Eswatini }\end{array}$ & 2010 & Yes & Unknown & - \\
\hline & & & & & Malawi & 2019 & Yes & Variable & $\begin{array}{l}\text { Possibly } \\
\text { specificity }\end{array}$ \\
\hline & & & & & Mozambique & 2017 & Yes & Unknown & - \\
\hline & & & & & Zambia & 2019 & Yes & Variable & $\begin{array}{l}\text { Possibly } \\
\text { specificity }\end{array}$ \\
\hline & & & \multirow{3}{*}{$\begin{array}{l}\text { Intentionally } \\
\text { introduced }\end{array}$} & Africa & South Africa & 2007 & Yes & Variable & $\begin{array}{l}\text { Host plant } \\
\text { resistance } \\
\text { Climate }\end{array}$ \\
\hline & & & & Australia & Australia & 2012 & Yes & Variable & $\begin{array}{l}\text { Possibly } \\
\text { predation } \\
\text { Specificity }\end{array}$ \\
\hline & & & & North America & USA & 1976 & Yes & Unknown & - \\
\hline \multirow{5}{*}{$\begin{array}{l}\text { Aceria malherbae } \\
\text { Nuzzaci }\end{array}$} & \multirow{5}{*}{$\begin{array}{c}\text { gall- } \\
\text { making }\end{array}$} & \multirow{4}{*}{$\begin{array}{l}\text { Convolvulus arvensis L. } \\
\text { (Convolvulaceae; field bindweed) }\end{array}$} & \multirow{4}{*}{$\begin{array}{l}\text { Intentionally } \\
\text { introduced }\end{array}$} & Africa & South Africa & 1994 & No & - & Land use \\
\hline & & & & \multirow[b]{3}{*}{ North America } & Canada & 1989 & Yes & Unknown & Climate \\
\hline & & & & & Mexico & 2004 & No & - & - \\
\hline & & & & & USA & 1989 & Yes & Variable & $\begin{array}{l}\text { Possibly host } \\
\text { plant } \\
\text { resistance } \\
\text { Climate }\end{array}$ \\
\hline & & $\begin{array}{c}\text { Calystegia sepium (L.) R. Br. } \\
\text { (Convolvulaceae; hedge bindweed) }\end{array}$ & $\begin{array}{l}\text { Intentionally } \\
\text { introduced }\end{array}$ & North America & USA & 1993 & Unknown & Unknown & - \\
\hline $\begin{array}{c}\text { Aceria salsolae } \\
\text { de Lillo \& Sobhian }\end{array}$ & vagrant $^{2}$ & $\begin{array}{c}\text { Salsola tragus L. } \\
\text { (Chenopodiaceae; Russian thistle) }\end{array}$ & Petition submitted ${ }^{4}$ & North America & USA & 2004 & - & - & - \\
\hline
\end{tabular}


Table 1. Cont

\begin{tabular}{|c|c|c|c|c|c|c|c|c|c|}
\hline Eriophyid Mite Species & Ecological Class & Target Species & Status & Region & Location & Year & Establishment & Impact & $\begin{array}{l}\text { Limiting } \\
\text { Factors }\end{array}$ \\
\hline Aceria sp. & $\begin{array}{c}\text { gall- } \\
\text { making }\end{array}$ & $\begin{array}{l}\text { Chrysanthemoides monilifera (L.) } \\
\text { Norl. subsp. monilifera } \\
\text { (Asteraceae; boneseed) }\end{array}$ & $\begin{array}{l}\text { Intentionally } \\
\text { introduced }\end{array}$ & Australia & Australia & 2008 & Yes & Slight & $\begin{array}{l}\text { Possibly } \\
\text { predation } \\
\text { Climate }\end{array}$ \\
\hline $\begin{array}{l}\text { Aceria vitalbae } \\
\text { (Canestrini) }\end{array}$ & $\begin{array}{c}\text { gall- } \\
\text { making }\end{array}$ & $\begin{array}{c}\text { Clematis vitalba } \mathrm{L} \text {. } \\
\text { (Ranunculaceae; old-man's beard) }\end{array}$ & Petition approved ${ }^{5}$ & Pacific & New Zealand & 2018 & - & - & - \\
\hline $\begin{array}{l}\text { Aculus crassulae } \\
\text { Knihinicki \& } \\
\text { Petanović }\end{array}$ & $\begin{array}{l}\text { gall- } \\
\text { making }\end{array}$ & $\begin{array}{l}\text { Crassula helmsii (Kirk) Cockayne } \\
\text { (Crassulaceae; swamp stonecrop) }\end{array}$ & $\begin{array}{l}\text { Intentionally } \\
\text { introduced }^{6}\end{array}$ & Eurasia & UK & 2018 & Too early ${ }^{7}$ & Too early & - \\
\hline \multirow[t]{2}{*}{$\begin{array}{l}\text { Aculus hyperici } \\
\text { (Liro) }\end{array}$} & \multirow[t]{2}{*}{ vagrant } & \multirow[t]{2}{*}{$\begin{array}{l}\text { Hypericum perforatum L. } \\
\text { (Hypericaceae; St John's wort) }\end{array}$} & \multirow[t]{2}{*}{$\begin{array}{l}\text { Intentionally } \\
\text { introduced }\end{array}$} & \multirow[t]{2}{*}{ Australia } & \multirow[t]{2}{*}{ Australia } & 1985 & No & - & $\begin{array}{c}\text { Possibly } \\
\text { predation } \\
\text { Possibly } \\
\text { parasitism }\end{array}$ \\
\hline & & & & & & 1991 & Yes & Slight & $\begin{array}{l}\text { Host plant } \\
\text { resistance }\end{array}$ \\
\hline \multirow{2}{*}{$\begin{array}{l}\text { Cecidophyes rouhollah } \\
\text { Craemer }\end{array}$} & \multirow{2}{*}{$\begin{array}{l}\text { gall- } \\
\text { making }\end{array}$} & \multirow{2}{*}{$\begin{array}{l}\text { Galium aparine } \mathrm{L} . \\
\text { (Rubiaceae; cleavers) }\end{array}$} & Adventive & Pacific & New Zealand & 2017 & Yes & Unknown & $\begin{array}{c}\text { Possibly } \\
\text { predation }\end{array}$ \\
\hline & & & $\begin{array}{l}\text { Intentionally } \\
\text { introduced }\end{array}$ & North America & Canada & 2003 & No & - & Climate \\
\hline \multirow{2}{*}{$\begin{array}{l}\text { Colomerus spathodeae } \\
\text { (Carmona) }\end{array}$} & \multirow{2}{*}{$\begin{array}{l}\text { gall- } \\
\text { making }\end{array}$} & \multirow{2}{*}{$\begin{array}{l}\text { Spathodea campanulata P. Beauv. } \\
\text { (Bignoniaceae; African tulip tree) }\end{array}$} & Adventive & Africa & Malawi & 2019 & Yes & Unknown & - \\
\hline & & & $\begin{array}{l}\text { Intentionally } \\
\text { introduced }^{8}\end{array}$ & Pacific & Cook Islands & 2017 & Yes & Unknown & - \\
\hline $\begin{array}{l}\text { Floracarus perrepae } \\
\text { Knihinicki \& Boczek }\end{array}$ & $\begin{array}{c}\text { gall- } \\
\text { making }\end{array}$ & $\begin{array}{l}\text { Lygodium microphyllum (Cav.) R. Br. } \\
\text { (Lygodiaceae; Old World climbing } \\
\text { fern) }\end{array}$ & $\begin{array}{l}\text { Intentionally } \\
\text { introduced }\end{array}$ & North America & USA & 2008 & Yes & Variable & Specificity \\
\hline $\begin{array}{l}\text { Phyllocoptes } \\
\text { fructiphilus Keifer }\end{array}$ & $\begin{array}{c}\text { gall- } \\
\text { making }\end{array}$ & $\begin{array}{l}\text { Rosa multiflora Thunb. } \\
\text { (Rosaceae; miltiflora rose) }\end{array}$ & Adventive & North America & USA & 1968 & Yes & Variable & Plant stage \\
\hline
\end{tabular}

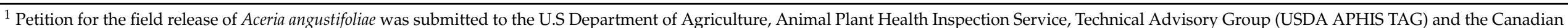

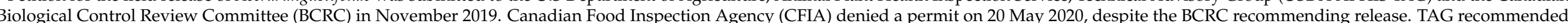

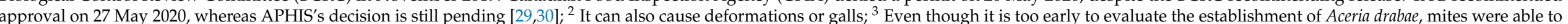

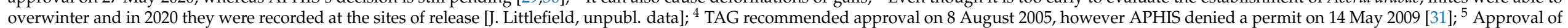

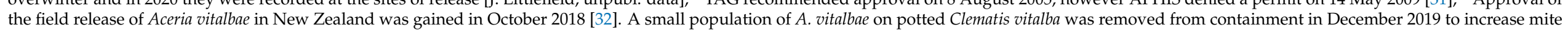

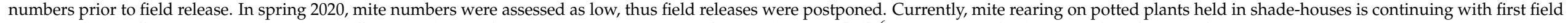

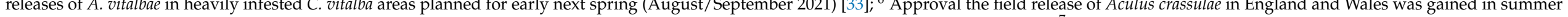

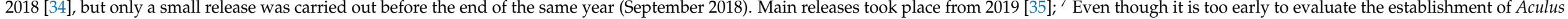

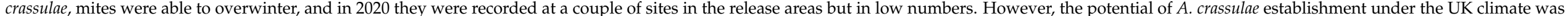

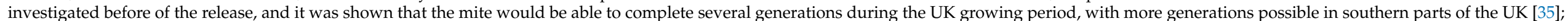


In the context of classical biological control of weeds, working with eriophyid mites may be particularly difficult, starting from the lack of knowledge regarding their biology, ecology, and behavior. Due to their microscopic size and tendency to hide within plant structures (e.g., galls, various deformations or common protective organs), the handling and rearing of eriophyid mites is particularly challenging, as is making any direct observations on them [21]. Moreover, some eriophyid mites are highly coevolved with their host plant, and they may be ineffective biological control agents because of reduced harmfulness of the mite and/or high tolerance of the plant [23]. Susceptibility of eriophyids to biotic (e.g., host plant resistance and natural enemies) and abiotic (e.g., soil composition, rain, wind and climate) factors may also prevent them from achieving the densities necessary to reduce host plant populations, and thus impact the target weed $[23,26]$ (for examples see limiting factors in Table 1).

\section{Modern Taxonomy and Its Role in Improving Classical Biological Control Programs}

Building on the traditional morphological approach to the identification and/or description of an eriophyid mite, new trends appeared in the last decade, paving the way towards integrative taxonomy [37]. Nowadays, methods of linear and geometric morphological analysis are applied more frequently, since they allow studying intraspecific variation, including host-adapted strains, host-races, or even cryptic species. These phenomena are particularly common in eriophyid mites because of the intimate association with their hosts, the lack of long-distance host seeking ability, and high reproductive rates $[38,39]$. Molecular genetic tools, which have begun to be employed in eriophyid mite studies [40], should further advance mite taxonomy. In particular, a complex approach using the combined techniques of phase-contrast light microscopy, diffraction interference contrast microscopy, confocal laser scanning microscopy (CLSM), and scanning electron microscopy (SEM), as well as sequencing of standard DNA regions, including the mitochondrial gene cytochrome oxidase subunit I (mtCOI) and nuclear regions such as the internal transcribed spacers ITS1 and ITS2, supports the description of eriophyid mites with much more detail, much of which is also quantifiable, than before $[40,41]$.

An integrative approach can help in establishing reliable criteria to determine species in Eriophyoidea. Most papers published today concerning alpha-taxonomy are prepared following traditional methods, but there are increasing numbers of species descriptions employing methods of traditional morphological taxonomy combined with the support of DNA sequences of one (typically mtCOI) or a few genetic regions [42-45]. For example, the newly recognized species Aceria artemisiifoliae Vidović \& Petanović, a potential biological control agent of common ragweed (Ambrosia artemisiifolia L., Asteraceae), was described following both morphological and bio-molecular approaches [46].

The study of intraspecific phenetic and genetic variability in order to verify the current status of taxa began as early as the second half of 20th century, and the intraspecific variability of selected taxa was the subject of interest of some authors in the following decades. A quantitative approach with sample selection of adequate size and the use of restrictive statistical tests (i.e., multivariate analyses based on at least 30 individuals and more than 20 characters) was initiated by Skoracka et al. [47], followed by similar studies using linear and geometric morphometry to establish phenetic similarities or differences [48-52]. At the end of the first decade of the new century, such data began to be combined with molecular genetic analyses of the barcode region in order to obtain congruence with phenetics $[44,53,54]$.

Since the beginning of the last decade, the integrative approach to taxonomy of eriophyid mites has also been applied to the description of new candidates for the biological control of weeds. For example, studies on complexes of mite populations occurring sympatrically on closely related host plants have contributed to the discovery of some cryptic species of the genus Aceria, such as those within Aceria anthocoptes (Nalepa) complex (i.e., A. anthocoptes s.s. ex Cirsium arvense; A. cf. anthocoptes ex C. heterophyllum; A. cf. anthocoptes ex $C$. eriophorum and $A$. cf. anthocoptes ex $C$. creticum, with genetic divergence 
ranging from $11 \%$ to $18.1 \%$ [55]) or the four cryptic species from Aceria drabae (Nalepa) complex (i.e., Aceria auriniae n.sp. ex Aurinia petraea, Aceria berteroae n.sp. ex Berteroa incana and Aceria sisymbrii n.sp. ex Sisymbrium orientale, with genetic divergence ranging from $14.4 \%$ to $25.9 \%[56])$.

Studies of Eurasian populations of some species belonging to the genera Aculodes and Metaculus are currently ongoing. In particular, after the description of Aculodes altamurgiensis de Lillo \& Vidović from medusahead (Taeniatherum caput-medusae (L.) Nevski, Poaceae) [57], a morphologically similar mite was found on cheatgrass (Bromus tectorum L., Poaceae), occurring sympatrically with A. altamurgiensis on medusahead. However, the quantitative morphometric analysis showed divergence between the two mites, which was also confirmed by measuring the genetic divergence (mtCOI distance $=18 \%$ ). Thus, by using an integrative approach it was possible to determine that the two mite populations occurring on medusahead and cheatgrass, respectively, are actually two distinct species [58].

The phenomenon of cryptic speciation was also recorded in mites of the genus Metaculus, some of which have been evaluated as biological control agents of some Brassicaceae. To date, three Metaculus species have been recorded, i.e., M. lepidifolii Monfreda \& de Lillo ex Lepidium latifolium, M. rapistri Carmona ex Rapistrum rugosum and M. diplotaxi Petanović \& Vidović ex Diplotaxis tenuifolia $[45,59,60]$. Metaculus rapistri was initially described by Carmona (1969) from samples of $R$. rugosum collected in Portugal. Thereafter, a supplementary morphological description of this species was provided by Monfreda and de Lillo [60] from samples of Isatis tinctoria L. collected in Turkey. In 2017, M. rapistri ex I. tinctoria was recorded at two more localities, in Italy and Germany. Further research of quantitative morphometric characteristics and analysis of mtCOI sequences showed the existence of cryptic species within the M. rapistri complex, and M. rapistri ex R. rugosum is a distinctly different species than Metaculus sp. ex I. tinctoria. Furthermore, the Metaculus sp. ex I. tinctoria population from Turkey is different from the specimens from Germany and Italy, which indicates the existence of two cryptic species adapted to the same host plant [61,62].

In morphological and molecular investigations on eriophyid mites from Russian olive (Elaeagnus angustifolia L., Elaeagnaceae) no differences were observed among Aceria angustifoliae Denizhan et al. populations collected at various sites in Eurasia (i.e., Serbia, Iran, Uzbekistan and Armenia) suggesting a single species [63].The morphological comparison of these populations with those found on Russian olive in the USA (i.e., Wyoming, Colorado, and Montana) suggested the existence of A. angustifoliae in the USA. However, molecular analysis showed that, although the American populations belonged to the genus Aceria, they were genetically different from A. angustifoliae in Eurasia. Molecular comparisons with eriophyid mites collected from other Elaeagnaceae, resulted in a match with an undescribed species collected from the North American native E. commutata L. These data mean that $A$. angustifoliae occurring on Russian olive of Palearctic origin is not yet recorded in the USA, however, morphologically these may be considered cryptic species with those on E. commutata, which has implications for future monitoring of biological control of Russian olive in North America [30].

The modern taxonomic approach was also important for the identification of Aceria acroptiloni Shevchenko \& Kovalev. When this species was described, three morphs were observed on Russian knapweed (Rhaponticum repens (L.) Hidalgo, Asteraceae) [64]. Based on morphological investigation using conventional light microscopy and a more precise CLS microscopy, it was possible to determine that these morphs were three different mite species, all occurring on the same host plant [65].

Another example of the usefulness of the integrative taxonomy approach is the resolution of the identification of at least two of the four eriophyid mite species recorded on tree of heaven (Ailanthus altissima (Mill.) Swingle, Simaroubaceae), i.e., Aculops taihangensis Hong \& Xue and Aculus mosoniensis (Ripka). Based on morphological observations, de Lillo et al. [66] suggested that $A$. taihangensis and Ac. mosoniensis were likely synonymous, and the subsequent molecular comparison showed no significant variation in nuclear 
region ITS1 ( $p$-distance $=0.02 \pm 0.02 \mathrm{bp}$ ) confirming the synonymy of the two species [67]. The same approach could help solve the identification of the other two species recorded on tree of heaven, i.e., A. ailanthi Lin, Jin, \& Kuang, and Ac. altissimae Xue \& Hong. In fact, according to Amrine J., Ac. altissimae may be a junior synonym of $A$. ailanthi, because the morphological differences between the species are slight and may be attributable to procedural-artifacts (e.g., over clearing specimens prior to slide mounting, differences in interpretation of characters of slide mounted specimens, poorly made illustrations) [68]. This last point raises one more issue. Different authors can use different slide mounting methods, and this may affect the comparison of the descriptions. Overclearing, underclearing, body stressing, flattening, squashing, imprecisions in measurements, microscopy details, and experience of the operators: all these aspects may lead to mistakenly perceived differences among specimens observed by different scientists. Therefore, it is important to use standardized protocols for morphological observations to minimize such discrepancies [69].

In contrast to the previously mentioned examples is the case of Aceria alhagi Vidović \& Kamali, a promising candidate for the control of camelthorn (Alhagi maurorum Medik., Fabaceae) [70]. Investigations of genetic variability by molecular analyses (mtCOI) among populations from Iran, Turkey and Armenia showed genetic divergence ranging from 0.0 to $0.6 \%$, suggesting that they represent one species [71]. These data suggest that some eriophyid species appear to be very uniform over wide geographic areas, whereas some others show a wide intraspecific phenetic and genetic variability. For example, the study of $A$. anthocoptes s.s. ex $C$. arvense populations from different regions showed that the geographical factor may have an impact on both phenetic and genetic variability $[51,55]$. Landmark-based geometric morphometric methods to study morphological variability of three body regions (ventral, coxigenital and prodorsal) revealed significant differences between A. anthocoptes s.s. inhabiting European (Serbia) and North American (Colorado) C. arvense. Moreover, European populations of $A$. anthocoptes s.s. from $C$. arvense are characterized by higher inter-population size and shape variability than their North American counterparts [55]. Finally, molecular comparisons of seven populations from different localities in Serbia showed a genetic divergence ranging from 5.6\% to 6.2\% [59]. There is still debate around the threshold (i.e., the percentage of genetic divergence) for distinguishing eriophyid species on the basis of COI gene. The first report was presented by Skoracka and Dabert [72], who showed that reproductively incompatible strains of Abacarus hystrix exhibit more than $20 \%$ sequence divergence in the COI gene and $0.2 \%$ sequence divergence in the nuclear D2 region of $28 \mathrm{~S}$ rDNA. A barcoding gap analysis identified the gap for within- and between-species to be 13 to $15 \%$ for COI sequences within the Abacarus histrix s.l. complex [73]. Studies of other taxa have reported a range of interspecific and intraspecific distances, but without a gap analysis (e.g., [53,57,74,75]).

\section{Evaluation of Eriophyid Mite Host Plant Specificity, and Its Implications}

Eriophyid mites are considered to be often highly host-specific, but it should not be forgotten that in the past their host ranges have been mainly deduced on the basis of collection records often based on few samples, instead of being determined by quantitative field data or experimentation [22,76]. The increasing interest in the use of eriophyid mites as agents for the biological control of weeds, as well as the need to control agronomic pest species (e.g., Aceria tosichella Keifer, Cecidophyopsis ribis (Westwood), Aceria cajani Channabasavanna [77-79]), has led scientists to increase the effort to better understand their host plant interaction and potential host range and, resulting in significant improvements of the host-specificity screening methods.

Since the beginning of regulated biological control, laboratory tests have been used to distinguish those nontarget plant species that are clearly not suitable hosts for the candidate mite agent, even though they may be closely related to the target species [80]. These bioassays measure parameters such as adult feeding, oviposition and larval development of the prospective candidate on various host species and are often carried out in confined spaces 
and under artificial conditions and may produce results that differ from natural behavior in the field. On the other hand, open-field tests imply the total absence of artificial barriers (e.g., screens, cages, tubes, etc.) to the natural movement of the agent, and to its natural enemies, as well as to the exposure to natural environmental conditions. Therefore, under field conditions, the agent can show its natural behavior and exercise a free choice $[81,82]$. Eriophyid mites are mainly dispersed by wind ([39,83-86] and references therein) and hence have limited chance to depart from unsuitable plants under laboratory conditions (e.g., for lack of air movement or physical contact between different host plants), which may increase the tendency of the mites to probe and/or feed on nontarget plants. Consequently, laboratory experiments with eriophyid mites are generally no-choice (starvation) tests, which may delineate the fundamental (or physiological) host range. However, this may yield 'false-positive' results and overestimate the risk of attack under field conditions, so the results obtained by them should be interpreted cautiously $[80,87]$. Conducting host specificity tests in the field may be the best way to assess the realized (or ecological) host range, which is usually a sub-set of the fundamental one [82], and to validate the results obtained by laboratory experiments.

During the past 30 years, the study of eriophyids in field experiments has significantly increased [22], and several species have been shown to be host specific in the field, even though they were observed to develop on and damage some nontarget plants under laboratory or greenhouse conditions (e.g., A. hyperici and A. malherbae biological control agents of St. John's wort (Hypericum perforatum L., Hypericaceae) and field bindweed (Convolvulus arvensis L., Convolvulaceae), respectively; Aceria centaureae (Nalepa), a candidate agent of diffuse knapweed (Centaurea diffusa Lam., Asteraceae) ([23] and references therein)). For example, Aceria solstitialis de Lillo, Cristofaro et Kashefi, a candidate for the control of yellow starthistle (Ce. solstitialis L., Asteraceae), showed a wider host range under artificial than in field conditions [88]. The mite was observed to persist (i.e., the plants remained infested with live mites) for as long as 60 days on some nontarget plants under laboratory conditions (i.e., Ce. diffusa; Ce. cyanus L., Carthamus tinctorius L. and Cynara scolymus L.), whereas in the field it was not found on most of nontarget species tested (mites occurred only on Ce. solstitialis and Ce. cyanus). Similar results were observed also for Aceria salsolae de Lillo \& Sobhian, a candidate agent against Russian thistle (Salsola tragus L., Chenopodiaceae) $[31,89,90]$. In laboratory experiments $A$. salsolae produced small populations on some nontarget species (i.e., Atriplex coronata S. Watson, Bassia hyssopifolia (Pallas) Kuntze, B. prostrata (L.) A.J. Scott, Kochia scoparia (L.) Schrader, and Suaeda calceoliformis (Hook.)), whereas in the field it was able to persist only on one of them (i.e., A. coronata) and at extremely low densities, with no evidence of reproduction (i.e., no juveniles were found) [31].

Eriophyid mites represent a potential risk for nontarget species if they are able to at least persist (i.e., survive) on these plants. Life expectancy of eriophyid mites is still poorly known. Although 4 to 5 weeks has been reported for non-diapausing females (i.e., the protogyne morph) [91], eriophyid mites can survive even longer under cool conditions, especially if they are protected from desiccation and can obtain some nutrition. In a recent study on persistence of five eriophyid species in water droplets, mites survived for up to 1 to 11 days at $25^{\circ} \mathrm{C}$, depending on species and morph, and up to 1 to 7 weeks at $5{ }^{\circ} \mathrm{C}$ [92]. Aceria tulipae (Keifer, 1938), which today would be identified as A. tosichella [93], survived at least 80 days on potato dextrose agar (being tested as an artificial substrate), but they did not oviposit until they were transferred to wheat plants [94]. In order to estimate eriophyid survivorship, it is important to monitor through time the mite population on the plants. For example, during the first host specificity field experiment with Ac. mosoniensis, by performing more than one sampling, it was found that the mite can persist for at least one month on two nontarget species among those tested. In particular, at 34 days after the inoculation of about 15 individuals on each plant, a few live mites were recorded on the nontarget hosts Juglans regia L. and Quercus ilex L. (i.e., 11 and 8, respectively) compared to thousands of live Ac. mosoniensis collected from its natural host, tree of heaven (i.e., 9218). 
At 47 days post-inoculation, no live mites were found on any of the nontarget plants (only 3 and 1 dead mite were remaining on J. regia and $Q$. ilex, respectively), while on tree of heaven the number of live mites further increased (i.e., 16,868). A second experiment determined that Ac. mosoniensis can survive even longer (i.e., up to two months) on some other nontarget species. In particular, live mites were found on Olea europaea L. and Rhus coriaria L. up to 63-days from the inoculation ( 3 and 1 live mite, respectively, compared to 5263 live Ac. mosoniensis collected from tree of heaven) [M. Cristofaro, unpubl. data]. The determination of the status of 'dead' or 'alive' of the specimens found on the plants is hence crucial for the estimation of the eriophyid mite survival. Moreover, since some species can be particularly long-lived even in suboptimal conditions, caution should be taken in choosing the duration of a host specificity experiment. Finally, due to their very small size, the identification of eriophyid mite species, whether by morphological or molecular methods, cannot be achieved without killing the individuals. This means that dead and live specimens have to be recorded and stored separately at the time of collection, because it is not possible to determine their status from preserved or mounted specimens.

The presence of live mites on nontarget plants does not necessarily mean they were able to survive on those plants. It is not unusual that mites found on nontarget plants during field experiments may have recently dispersed from nearby heavily-infested target plants $[23,26,88]$. Aerial dispersal is widely considered the main mode of dispersal for eriophyid mites $[39,86,95]$, and mites presumably have little or no control over where they land, so behavioral selectivity might involve assessing the plant and either staying to feed or dispersing by the next available wind [96]. Therefore, it is important to distinguish between 'transitory' live mites found on nontarget plants and signs of infestation. During field surveys of A. acroptiloni in Iran, very low densities of the mite were recorded on several nontarget plants (i.e., Onopordum sp., Carthamus sp., C. lanatus L., C. oxyacantha M.Bieb., Centaurea squarrosa Willd., Lactuca serriola L.), even though there was no evidence of symptoms due to feeding activity. By using water pan traps to detect aerially dispersing mites [86], it was concluded that the few A. acroptiloni recorded were actually mites randomly dispersing and could be considered transitory visitors [97].

The level of injuries caused by arthropods attacking a plant generally depends on the density of individuals present [98], unless other factors are also involved (e.g., plant pathogens, stressful climatic conditions, etc.). Therefore, in the case of a prospective biological control agent that persists on a nontarget plant, it is particularly important to determine if it can multiply enough to achieve population densities that impact the plant [18]. Assessing the population structure (i.e., the number of eggs, nymphs and adults, and also of males and females) after suitable time can help to determine if the mite is able to reproduce and develop a population on the plant, and how big this could become, especially if the starting number of mites inoculated is known. During a laboratory no-choice study, A. salsolae was observed to persist for up to 5 weeks and even reproduce on one of the nontarget species, A. coronata, but it never attained populations anywhere close to those that developed on S. tragus [31]. However, in the field the mite could persist for up to 9 weeks, but the absence of juveniles indicated that no reproduction occurred. These data suggest that even though A. salsolae could persist for a long time on A. coronata, the mite did not reproduce on it under natural field conditions. Thus, as in the case of Ac. mosoniensis, some plants may be suitable enough to support survivorship but not necessarily reproduction of the eriophyids and hence are not likely to be harmed by the mites.

Ability to reproduce on nontarget species does not necessarily mean that mites will cause significant damage. For example, although able to develop on some nontarget plants in pre-release studies, A. hyperici was released in Australia as a biological control agent against St. John's wort (Table 1). The mite survived and reproduced on at least four nontarget species, including a species native to Australia (Hypericum gramineum G.Forst.) [24]; however, it had negligible impact on all measured indices of growth and reproduction of this plant in the field and therefore was not considered harmful [99]. On the other hand, even the induction of plant injuries is not necessarily a sign of successful mite reproduc- 
tion $[100,101]$. This is the case of A. malherbae, which was released in the USA and South Africa against field bindweed (Table 1), even though it caused galling on three Convolvulus and 12 Calystegia species in laboratory and screen house studies [100-103]. In laboratory studies, galling, but not reproduction, was observed on the Calystegia species while both occurred on field bindweed $[100,101]$. In a field experiment, galling was observed on several nontarget species during the summer in which mites were inoculated, but not the following year, suggesting either failure of reproduction and/or survival of $A$. malherbae through the winter (which normally occurs underground on the roots), whereas field bindweed was galled the following year (Hansen, R.W. pers. comm. in [23]). These data suggested that mite requirements for reproduction are more restrictive than for gall induction [100]. In the field, both A. malherbae and A. hyperici have not had significant impact on nontarget species that are known to be within their physiological host range. Thus, in cases where a nontarget species is attacked under no-choice conditions (i.e., laboratory conditions), assessing the risk of attack under more natural conditions may provide convincing evidence of the safety of the candidate as biological control agent [87]. Furthermore, as shown in the cases of A. hyperici on H. gramineum [99] and A. salsolae on A. coronata [31], it is important to quantify any reduction in fitness (size, survivorship or reproduction) of the nontarget plant by the agent [28].

The kind and severity of the induced symptoms depend on the host-mite specificity and mite density, but also on the organs infested, phenology and physiological conditions of the plant. Therefore, in order to produce results that accurately predict risk of damage to nontarget plants in the field, experiments have to be designed based on knowledge of the life history of both the eriophyid mites and plants. Plants have to be at a suitable developmental stage, with plant structures vulnerable to the mites. Plants that do not have tissue at the right stage for inducing galls may mask susceptibility, whereas those that have softer tissue due to the artificial growing conditions could be more susceptible than normal.

Another critical aspect of the risk assessment for nontarget species to be attacked by a prospective biological control agent is the duration of experiments to ensure that any possible injury would be observed. Marini et al. [31] inoculated $A$. salsolae on test plants when they were little bigger than seedlings, providing to the mites tender tissues on which they could feed, and ended the experiment when each host species reached the mature growth stage (i.e., fruits). This approach allowed measuring the development of the mite population (as discussed above) and also recording and quantifying any potential impact on the plants, following both mites and plants for the whole season.

The use of eriophyid mites in the biological control of weeds also implies the possibility of dealing with biotypes of the target that are resistant or less susceptible to the mite selected as agent for its control [104]. Variability in the susceptibility of the target weed to its agent also should be considered as variability in the performance of the eriophyid on its target, in terms of colonization rate and impact, and hence in its efficacy against the target. This means that to ensure the introduction of an appropriate agent, and the success of its establishment, the phenotypic structure of the target weed should also be studied. In fact, the variability in the susceptibility of plants to mites is not uncommon, especially for those plant species which present different forms [24].

Aceria cynodoniensis (Sayed) is the best example of an extremely specific species, which can only develop on particular strains of Bermuda grass (Cynodon dactylon (L.) Pers., Poaceae) parentage, but not on hybrids [105]. Another example is A. chondrillae, whose populations from different regions are specialized on the corresponding forms of rush skeletonweed (Chondrilla juncea L., Asteraceae) from those same regions [106]. The plant has at least four different genotypes that vary in resistance to the mite $[107,108]$. The Greek mite strain was found to be highly effective against the predominant narrow-leaf form of rush skeletonweed in Australia, but it had low or no impact on the other forms of the weed present in Australia or in North America. On the other hand, the Italian mite strain induced galling on the North American forms of rush skeletonweed, but not on the most common form in Australia $[24,107,108]$. A similar pattern was observed for Floracarus 
perrepae Knihinicki \& Boczek. Extensive samplings, genetic analyses and laboratory tests revealed location-specific haplotypes of the mite and its host plant, Old World climbing fern (Lygodium microphyllum (Cav.) R. Br., Lygodiaceae), across the native distribution, and in particular that F. perrepae populations from various locations were best able to induce galls on the local fern haplotype [109]. Thus, both A. chondrillae and F. perrepae are examples of a high degree of specialization on different host-plant forms (i.e., hostadapted strains). In the case of A. hyperici, the plant has populations completely resistant to the mite. In particular, among the different populations of St. John's wort present in Australia, two of them did not support the development of A. hyperici populations, while the other four were susceptible, but showed some variations in population growth and impact on the plants [24]. This pattern is similar to what was also observed with A. malherbae on field bindweed, Aceria lantanae (Cook) on lantana (Lantana camara L., Verbenaceae) or A. altamurgensis on medusahead, for which variations in the susceptibility to infestation was experimentally demonstrated by testing different populations of their respective targets $[103,110-112]$. However, A. altamurgensis performed very poorly on the medusahead plants from the location where it was collected (i.e., Apulia, Italy), whereas it performed much better on plants from Sicily, Italy, and from Idaho and Nevada, USA [110]. Generalizing, these examples point out the importance of including multiple native- and invaded-range populations of the target weed in pre-release evaluations, but also to test additional mite strains to control resistant varieties of the target plant.

\section{Evaluation of Eriophyid Mite Impact on the Target Weed, and Its Implications}

Predicting and measuring impact of weed biological control agents is a challenging task and typically fewer resources are channeled into pre-release studies when compared to safety studies $[98,113]$. However, nowadays these studies are increasingly being conducted, and not only to reduce the probability of releasing an ineffective agent [114], but also, to better understand why certain biological control programs are a success while others fail $[115,116]$.

To date, the majority of eriophyid mites released have not had the expected impact that pre-release studies have predicted, but rather impact is typically variable across the landscape $[28,115]$, as turned out for A. malherbae. Laboratory studies indicated that the mite would be likely to achieve significant reductions in both shoot (37\%) and root biomass $(50 \%)$ of field bindweed [117], but this has not been the case throughout the range of field sites $[23,118]$. There is much speculation on the differences observed in the outcomes at the different sites; however, there appears to be a clear link between climatic variables and chances of success, with drier and warmer years resulting in a greater probability of success, with some sites having as much as $95 \%$ reduction in field bindweed [23]. Interestingly, particular land use patterns, such as mowing and herbicide application at sub-lethal doses, appear to be able to be integrated into the biological control program increasing the impact of this mite and success of the program in general $[117,119]$. This is not unique to this system and mowing has been investigated as an integrated management strategy for the control of the light pink 163LP variety of lantana using A. lantanae [120]. In particular, the combination of mowing did not seem to affect the mite's occurrence and infestation patterns [111], however, there was a 78.5\% increase in the number of galled inflorescences per shoot, when compared to plants that were not mowed [120]. These studies highlight potential problems of relying solely on laboratory studies. There are indeed many abiotic (e.g., climate, soil, wind, etc.) and biotic (e.g., pathogens, predators, host plant resistance, etc.) interactions which may limit the eriophyid mite impact once they are released in the field $[23,26]$. Thus, it is particularly important to gather information in the native and non-native range on potential limiting factors, not only climate, but also what effect particular land use patterns may have on mite populations and how these may influence the impact of the mite.

Field studies through observations and experiments have shown not only massive reductions in seed set of individual plants (e.g., $66 \%$ by A. angustifoliae against Russian 
olive [121], to $95 \%$ by $A$. alhagi against camelthorn [70], and up to $98 \%$ by $A$. acroptiloni against Russian knapweed [122]), but also, impressive reductions in biomass (e.g., 66\% reduction in size of Russian thistle by A. salsolae [89] and a 49\% reduction in above ground Old World climbing fern biomass by F. perrepae [123]). Although these results are encouraging, many of these experiments are conducted in the best possible conditions for establishment and rapid buildup of the mite population on plants. This can be achieved by early season inoculations to boost the population enough to achieve impact, or attempting several different methods of establishment in order to obtain the best results [122]. Moreover, experimental set ups are usually short-term (1-2 years) and at individual plant level. For example, the only feasible way to obtain an impact assessment of A. angustifoliae, although establishment was successful, was to collect data from existing infestations under natural conditions, by comparing branches infested with mites with those that were free of mite attack [121]. This resulted in an estimated 2/3 reduction in seed set on infested branches by not only affecting fruit production directly, but by also reducing the length of fruit bearing branches, further compounding the impact [121]. Although this suggests a high level of impact and will likely slow the invasion potential of Russian olive in North America, there are certain limitations linked to observational data. Such as, it is unclear whether the mites are present and impactful on certain branches or trees that are inherently unlikely to produce many fruits. By selecting for mite infested branches on particular trees, it is possible that the impact may be overestimated, and thus, difficult to translate the individual branch level to the population level.

Factors that limit or influence eriophyid mites under field conditions may be so subtle that they can be difficult to detect or understand. To cite an instance, after a successful impact experiment with A. acroptiloni in Shirvan, northern Iran [122], due to logistical reasons, the host range experiments were moved to Mashhad, about $200 \mathrm{~km}$ to the southeast [26], but establishment on the control plants failed despite trying different techniques for six years [124]. In this case there was a slight altitudinal drop from $1100 \mathrm{~m}$ to $980 \mathrm{~m}$ above sea level, however, no quantifiable differences were detected comparing several abiotic factors, such as soil structure and type as well as a suite of climatic variables [26]. Due to this, it was decided to suspend any further work with this species, since the limiting factors which contributed to the failed establishment after moving just $200 \mathrm{~km}$ were not identified, it is unlikely that $A$. acroptiloni will establish and successfully control Russian knapweed in North America [124].

In the case of $F$. perrepae, pre-release impact experiments revealed that the mite was capable of a significant reduction in above ground (by $49 \%$ ) and below ground (by $35 \%$ ) Old World climbing fern biomass [123], however, this level of impact is yet to be observed in the field. A likely explanation of the limited impact could be linked to host plant susceptibility (also discussed above) [125] however, predators and pathogens known to impact mite populations [123] cannot be completely ruled out. Although predators and pathogens were observed to reduce the mite populations, there appeared to be little or no measurable effect on the impact of F. perrepae [123]. In a recent study, David et al. [126] identified wind speed to be positively associated with mite densities and suggested it may be directly linked to within and between site dispersal, ultimately influencing the probability of establishment and impact. Another study showed how the time of year and degree of shading could affect the impact of this mite on the growth of its host plant [127].

The identification of the limiting factors that are linked to a reduced impact is a challenging task, especially because sometimes they may not be obvious and/or rather related to the basic biology and behavior of eriophyids.

\section{Release and Post-Release Monitoring of Eriophyid Mites: Last but Not Least Steps of Classical Biological Control Programs}

Release and distribution of eriophyids for biological control of weeds generally follow after a progression of overseas collection, quarantine screening, establishment of rearing colonies, and initial releases leading to field establishment from which redistributions can be made ([128]). Although seemingly straight forward, the flow of agents may be 
hindered by procedural problems such as regulatory impediments, collection difficulties, and shipping delays, along with biological or ecological challenges that may pertain to each particular eriophyid mite. Overseas collections may be limited by international conventions, such as complying with requirements of the Nagoya Protocol on the Access to Genetic Resources and the Fair and Equitable Sharing of Benefits Arising from their Utilization, Convention on Biological Diversity $[129,130]$. Collections of agents or specific mite genotypes from some countries may be limited or impossible. For example, the collection and shipment of M. lepidifolii for perennial pepperweed (L. latifolium L., Brassicaceae) from Turkey was hampered by the difficulty of obtaining an export permit for the mite and by the political climate of that time in Turkey [131] As a result, surveys and subsequent collections of M. lepidifolii were moved from Turkey to Kazakhstan, from where export permits were obtainable [128]. A similar situation occurred with A. angustifoliae for which collections and experimental evaluations were moved from Iran and/or Turkey to Serbia, where the mite is also present [132].

Once regulatory approval for release is granted, the strategies for release and monitoring of eriophyid mites are similar to those of other arthropod agents utilized in classical biological control. However, due to their small size and ability to build to high populations, eriophyid mites could also lend themselves, like plant pathogens, to an inundative or bioherbicidal approach [133]. While nearly all eriophyid mites released for invasive weed management have been used in the classical approach, inundative methods should not be overlooked as an option in appropriate situations. Compared to insects, eriophyid mites are very small and are thus difficult to release as individuals and are generally released as a collective along with their host plant or infested plant tissue. For example, A. malherbae is distributed in Colorado by pulling or cutting infested field bindweed plants and placing the vegetation in paper bags which are given to the public, to be opened for release on their property [134]. The numbers of individuals available for initial releases from containment laboratories are usually limited. Prior to release into the environment, eriophyid agents have to be processed in a containment facility to screen out potential natural enemies such as phytoseiid mites, fungal pathogens of eriophyids, and other unwanted organisms such as other species of eriophyids, thrips, aphids, spider mites, etc. [135-138]. Mite identity is critical, especially on plant species that may harbor multiple eriophyid species, such as Scotch broom (Cytisus scoparius (L.) Link, Fabaceae) (two mite species, i.e., Aceria genistae (Nalepa) and Aceria davidmansoni Xue, Han \& Zhang) [139], and Russian knapweed (three mite species, as discussed above) $[65,97,122]$. Eriophyid mites are known vectors of plant pathogens, especially viruses or suspected viral agents [140]. Thus, there was concern about the risk of Cecidophyes rouhollahi Craemer, a prospective agent for cleavers (Galium spp.), because a related gall mite which attacks $G$. aparine $\mathrm{L}$. was thought to be associated with a plant virus [141]. Prior to release, mites were tested for 13 viral groups using PCR, with a second test conducted for false positives [142]. To further reduce the risk of accidental introduction of unwanted organisms, importations of eriophyid mites to containment facilities are limited in number. For example, for A. malherbae only one shipment was received and released in Texas, USA [143]; in Montana, USA, A. malherbae was imported for three years [144]; and two importations of C. rouhollahi were made in Canada [142]. For F. perrepae, only one importation was made from Australia to Florida, USA [125].

To initiate a rearing colony, a clean colony protocol of transferring individual mites to clean host plants is utilized. This protocol was employed with the broom gall mite, A. genistae [145] and with other mites including A. drabae [J. Littlefield, unpubl. data] and F. perrepae [125]. An alternative would be to inoculate plants using small pieces of gall or plant material that have been inspected and cleaned of other organisms [142,144]. Rearing colonies are sometimes established with limited numbers of mites due to low populations found during overseas collections, shipping mortality, and limited rearing space in containment facilities [146]. These containment rearing colonies serve as sources of mites for initial field release. Since containment colonies are generally unnecessary once the agent becomes established, little emphasis has been placed on efficient rearing techniques. 
For the augmentations of $A$. malherbae in Mexico, Rodriguez-Navarro et al. [147,148] did investigate inoculation levels and quality standards (number of mites per gall, number of galls per plants, infested stems, etc.) required for the successful laboratory rearing of a biocontrol agent over multiple generations without loss of genetic diversity [149,150].

The majority of eriophyid mites utilized for biological control of weeds are gallmakings, leaf distorters or rust mites. Release techniques to establish eriophyid mites have primarily relied on distributing galls or infested plant tissues or transplanting infested plants. Techniques may vary depending upon the intent of the release, e.g., initial release of a mite from containment with the goal of establishing populations or post-establishment redistribution either within site or to other locations. For example, the A. malherbae initial releases in Texas, USA [143], were made by inoculating potted plants and then transferring these to field plots. In Montana, USA, and Alberta, Canada [144], A. malherbae was released using two methods: either infested field bindweed plants from greenhouse rearing colonies were transplanted to field sites or infested leaves or stems were distributed at sites. Infested material was held next to healthy plants by twist ties or with Parafilm ${ }^{\circledR}$ or sections of split plastic straws. Both techniques were successful in Montana. Using infested plant material requires that there be close contact between infested and healthy plants. Friend et al. [151] reported that establishment of $A$. malherbae in Oklahoma, USA, was limited when infested material was simply placed on healthy plants. Wrapping infested stems around healthy stems improved successful transfer of the mite.

Once mites are established, they are often very effectively dispersed to new locations via wind. For example, A. malherbae in Montana was first established in the mid-1990s [144], and a follow-up survey conducted in 2007 showed that the mite was well dispersed across much of eastern Montana [152]. Aceria genistae first appeared as an adventive in North America in Tacoma, Washington, and Portland, Oregon, in 2005 [153]. In 2014, it was detected in California, at Georgetown and in the Sierra Nevada foothills, which is at least $760 \mathrm{~km}$ away. Pratt et al. [153] estimated that long range dispersal from Washington to California ranged from 39 to $62 \mathrm{~km} / \mathrm{yr}$. However, the fact that Sierra Nevada foothills were colonized by A. genistae prior to areas along the state's northern border or coast suggests that human-facilitated movement, such as by the movement of motorized vehicles or timber equipment may have been important. In any case, by 2017 the mite occurred over a region about $1500 \mathrm{~km}$ wide and at elevations ranging from 18 to $1160 \mathrm{~m}$ above sea level.

Post-release monitoring is generally designed to detect establishment, population density and dispersal of the agents; the degree of infestation or attack on target plants at the individual and/or population level; and possible impacts or interactions between biological control agents and nontarget organisms and/or critical habitats [116,154]. Biocontrol monitoring activities typically involve sampling arthropod populations along with target plant populations and the associated plant community. Monitoring protocols vary with the specific biocontrol agent and target plant $[155,156]$. Eriophyid populations may be measured directly by extracting mites from infested plant material [157-159]. The presence and dispersal of eriophyid mites in the field may also be detected by utilizing various traps including water pan traps, sticky traps or slides coated with silicone grease or petroleum jelly, or modified spore collection devices $[86,97,160]$. Indirect methods, such as counting galls or recording plant damage, are often employed due to ease and economy of sampling. Counts may be made on a per unit basis, either by area or by number of plants sampled, or on a timed basis. Accuracy of such counts may be dependent upon eriophyid population development, timing of samples, plant phenology, etc. More recently, DNA finger printing has been employed to determine genetic shifts with expanding mite populations and to track specific eriophyid genotypes/haplotypes, such as for the European broom gall mite, A. genistae, which is adventive in western USA [153]. Funding for release and postrelease monitoring of agents is often limited and frequently these activities are strictly aimed at the evaluation of the outcomes (e.g., agent establishment and impact) in term of management of the invasive weed. Schaffner et al. [116] suggested that an ecological approach to agent monitoring should also be investigated to predict and detect changes to 
ecosystem processes and services (e.g., food production, human health, tourism/recreation) brought about by biological control. They suggest that post-release monitoring can advance classical biological control of weeds by testing predictions or hypotheses derived from pre-release studies thus making monitoring more ecological and holistic in scope.

\section{Conclusions and Recommendations}

The importance of eriophyid mites, whether they are pests or biological control agents, is mainly due to the damage they can inflict on their hosts. These tiny plant feeders possess several of the desirable features for a biological control agent; however, in order to use them in weed classical biological control programs some important challenges must be overcome. Proper taxonomic identification of the eriophyid mite candidate is one of these. Nowadays, the use of advanced microscopic methods and molecular genetic tools, as well as studies of eriophyid biology, ecology, and behavior, is improving the description and characterization of eriophyid taxa. This modern approach to the taxonomy can facilitate investigations regarding eriophyid mites in general, and their interactions with the host plant, and consequently also their potential use as classical biological control agents of invasive weeds.

The growing demand in making biological control programs as safe as possible, and hence prevent any potential negative effect due to the release of the agent, imposes a deep understanding of the host range of the candidate and an accurate risk assessment for nontarget organisms. The achievement of these aims cannot ignore, especially in the case of eriophyid mites, the use of a combined approach of both laboratory and field tests. Moreover, the evaluation of the risk to nontarget plants cannot either overlook survival, reproduction, and development of the mite candidate on various host plants, or its ability to damage them.

The safety of the biological control agent released is usually considered a priority and has always been emphasized by regulatory agencies. However, characterization of impacts on the target and potential establishment in the introduced environment are just as important to the success of a classical biological control program, and more efforts and funds should be focused on these aspects.

Impact studies can be made particularly challenging by the phenomena of hostadapted mite strains or variability in the susceptibility of the plant to the mite. Therefore, genetic studies of both agent and target are crucial to approach properly this challenge. Moreover, it is important to consider eriophyid biology and ecology, as well as that of the target weed, and potential biotic and abiotic limiting factors before developing an experimental design and deciding how and which parameters to measure. An in-depth analysis of the potential limiting factors that could negatively affect the establishment and hence also the efficacy of the agent, can also support the release strategies and hence increase its potential success.

The final steps of release and post-release monitoring should not be underestimated, and the methods to accomplish them should be chosen with care according to the primary goals of the program. Post-hoc analyses of these steps are advantageous to improve the release strategies and favor the establishment of the agents, and hence increase the general success of classical biological programs. In particular, by the analysis of the results obtained by post-release monitoring activities, it is possible to understand if all challenges here mentioned have been successfully addressed.

Finally, it is important to highlight that, although eriophyid mites were first noted in the literature about 270 years ago and have been extensively investigated since the mid-19th century, studies on their biology, ecology and behavior have only been undertaken for a few decades, and rather sparsely. A long list of unresolved questions could be proposed, such as regarding their life history and physiological adaptation (e.g., survival strategies in relation to the host plant species, and to environmental conditions), or the interactive mechanisms between them and their hosts (e.g., biochemistry of mite-plant relationships; attractive, acceptance and repellence mechanisms of the host plant; possible co-evolution 
and speciation phenomena). Biological control programs would definitely benefit from this knowledge, which would help improve the design of the experiments to test host specificity, assess the risk of nontarget species, and evaluate the impact on the target. It would also help improve interpretation of the results obtained, and guide practical aspects directly connected with putting in place a biological control program and improve its general success. For example, the knowledge of the mechanisms and factors influencing the dispersal of eriophyid mites is of great importance for managing and monitoring their release, but also for predicting their success in colonization and establishment.

In conclusion, although eriophyid mites seem to have what it takes to become one of the best groups of biological control agents, it is clear that to attain this status scientists need to learn how to better deal with them, starting from increasing the knowledge of their basic biology, ecology and behavior. Unfortunately for eriophyid mites, one size does not fit all, and each individual species or system will have its own challenges, however, the potential benefits do out weight the costs.

Author Contributions: Conceptualization, F.M.; writing-original draft preparation, F.M., P.W., B.V., R.P. and J.L.; writing-review and editing, L.S., E.d.L., S.S. and M.C.; visualization, F.M.; supervision, L.S. All authors have read and agreed to the published version of the manuscript.

Funding: Funding was provided by the Montana Agricultural Experiment Station and projects MONB00129 and MONB00167 (Littlefield J.).

Institutional Review Board Statement: Not applicable.

Data Availability Statement: Not applicable.

Acknowledgments: We thank the following people for providing unpublished information: Lindsay Smith and Arnaud Cartier, Manaaki Whenua Landcare Research, Lincoln, New Zealand; Solan Varia, CABI, Egham, United Kingdom; Dan Bean, Colorado Department of Agriculture, Palisade, Colorado, United States.

Conflicts of Interest: The authors declare no conflict of interest.

\section{References}

1. Van Kleunen, M.; Dawson, W.; Essl, F.; Pergl, J.; Winter, M.; Weber, E.; Kreft, H.; Weigelt, P.; Kartesz, J.; Nishino, M. Global exchange and accumulation of non-native plants. Nature 2015, 525, 100-103. [CrossRef] [PubMed]

2. Beck, K.G.; Zimmerman, K.; Schardt, J.D.; Stone, J.; Lukens, R.R.; Reichard, S.; Randall, J.; Cangelosi, A.A.; Cooper, D.; Thompson, J.P. Invasive species defined in a policy context: Recommendations from the Federal Invasive Species Advisory Committee. Invasive Plant Sci. Manag. 2008, 1, 414-421. [CrossRef]

3. Cox, G.W. Alien Species in North America and Hawaii. Impacts on Natural Ecosystems; Island Press: Washington, DC, USA, 1999; ISBN 978-1-55963-680-3.

4. Pimentel, D.; McNair, S.; Janecka, J.; Wightman, J.; Simmonds, C.; O’Connell, C.; Wong, E.; Russel, L.; Zern, J.; Aquino, T. Economic and environmental threats of alien plant, animal, and microbe invasions. Agric. Ecosyst. Environ. 2001, 84, 1-20. [CrossRef]

5. Pimentel, D.; Zuniga, R.; Morrison, D. Update on the environmental and economic costs associated with alien-invasive species in the United States. Ecol. Econ. 2005, 52, 273-288. [CrossRef]

6. Lockwood, J.L.; Hoopes, M.F.; Marchetti, M.P. Invasion Ecology, 2nd ed.; Wiley-Blackwell Publications: London, UK, 2013; ISBN 978-1-4443-3364-0.

7. Kelton, J.A.; Price, A.J. Weed science and management. In Soils, Plant Growth and Crop Production, Encyclopedia of Life Support Systems (EOLSS); Verheye, W.H., Ed.; EOLSS Publications: Oxford, UK, 2010; Volume 3, pp. 76-101. ISBN 1-84826-369-4.

8. Culliney, T.W. Benefits of classical biological control for managing invasive plants. CRC. Crit. Rev. Plant Sci. 2005, 24, 131-150. [CrossRef]

9. Sheley, R.L.; James, J.J.; Rinella, M.J.; Blumenthal, D.; Ditomaso, J.M. Invasive plant management on anticipated conservation benefits: A scientific assessment. In Conservation Benefits of Rangeland Practices: Assessment, Recommendations, and Knowledge Gaps; Briske, D.D., Ed.; Natural Resources Conservation Service, U.S. Department of Agriculture: Washington, DC, USA, 2011; pp. 291-336.

10. Fowler, S.V.; Syrett, P.; Hill, R.L. Success and safety in the biological control of environmental weeds in New Zealand. Austral Ecol. 2000, 25, 553-562. [CrossRef]

11. McFadyen, R.E.C. Biological control of weeds. Annu. Rev. Entomol. 1998, 43, 369-393. [CrossRef] 
12. Van Driesche, R.; Hoddle, M.; Center, T.D. Control of Pests and Weeds by Natural Enemies: An Introduction to Biological Control; Blackwell: Malden, MA, USA, 2008; Volume 473.

13. Wapshere, A.J.; Delfosse, E.S.; Cullen, J.M. Recent developments in biological control of weeds. Crop Prot. 1989, 8, 227-250. [CrossRef]

14. Schwarzländer, M.; Hinz, H.L.; Winston, R.L.; Day, M.D. Biological control of weeds: An analysis of introductions, rates of establishment and estimates of success, worldwide. BioControl 2018, 63, 319-331. [CrossRef]

15. Moran, V.C.; Hoffmann, J.H.; Zimmermann, H.G. Biological control of invasive alien plants in South Africa: Necessity, circumspection, and success. Front. Ecol. Environ. 2005, 3, 71-77. [CrossRef]

16. Syrett, P.; Briese, D.T.; Hoffmann, J.H. Success in biological control of terrestrial weeds by arthropods. In Biological Control: Measures of Success; Gurr, G.M., Wratten, S.D., Eds.; Kluwer Academic Publ: Dordrecht, The Netherlands, 2000 ; pp. 189-230.

17. Page, A.R.; Lacey, K.L. Economic Impact Assessment of Australian Weed Biological Control: Report to the CRC for Australian Weed Management; CRC for Australian Weed Management: Adelaide, Australia, 2006; ISBN 978-1-920932-55-8.

18. Hinz, H.L.; Winston, R.L.; Schwarzländer, M. How safe is weed biological control? A global review of direct nontarget attack. Q. Rev. Biol. 2019, 94, 1-27. [CrossRef]

19. Suckling, D.M.; Sforza, R.H.F. What magnitude are observed non-target impacts from weed biocontrol? PLoS ONE 2014, 9, e84847. [CrossRef]

20. de Lillo, E.; Skoracka, A. What's "cool" on eriophyoid mites? Exp. Appl. Acarol. 2010, 51, 3-30. [CrossRef]

21. Lindquist, E.E.; Sabelis, M.W.; Bruin, J. Eriophyoid Mites. Their Biology, Natural Enemies and Control; Elsevier Science Publishing: Amsterdam, The Netherlands, 1996.

22. Skoracka, A.; Smith, L.; Oldfield, G.; Cristofaro, M.; Amrine, J.W. Host-plant specificity and specialization in eriophyoid mites and their importance for the use of eriophyoid mites as biocontrol agents of weeds. Exp. Appl. Acarol. 2010, 51, 93-113. [CrossRef]

23. Smith, L.; de Lillo, E.; Amrine, J.W. Effectiveness of eriophyid mites for biological control of weedy plants and challenges for future research. Exp. Appl. Acarol. 2010, 51, 115-149. [CrossRef]

24. Cullen, J.M.; Briese, D.T. Host plant susceptibility to eriophyid mites used for weed biological control. In Proceedings of the Acarology: Proceedings of the 10th International Congress, Canberra, Australia, 5-10 July 1998; Halliday, R.B., Walter, D.E., Proctor, H.C., Norton, A.R., Colloff, M.J., Eds.; CSIRO Publishing: Collingwood, VIC, Australia, 2001; pp. 342-348.

25. de Lillo, E.; Pozzebon, A.; Valenzano, D.; Duso, C. An intimate relationship between eriophyoid mites and their host plants-A review. Front. Plant Sci. 2018, 9, 1786. [CrossRef]

26. Weyl, P.; Cristofaro, M.; Smith, L.; Schaffner, U.; Vidović, B.; Petanović, R.; Marini, F.; Asadi, G.A.; Stutz, S. Eriophyid mites and weed biological control: Does every silver lining have a cloud? In Proceedings of the XV International Symposium on Biological Control of Weeds, Engelberg, Switzerland, 26-31 August 2018; Hinz, H.L., Bon, M.C., Bourdôt, G., Cristofaro, M., Desurmont, G., Kurose, D., Müller-Schärer, H., Rafter, M., Schaffner, U., Seier, M., et al., Eds.; FHAAST-2018-06. 2019; pp. 9-11.

27. Winston, R.L.; Schwarzländer, M.; Hinz, H.L.; Day, M.D.; Cock, M.J.W.; Julien, M.H. Biological Control of Weeds: A World Catalogue of Agents and Their Target Weeds. Available online: https:/ /www.ibiocontrol.org/catalog/ (accessed on 22 January 2021).

28. Winston, R.L.; Schwarzländer, M.; Hinz, H.L.; Day, M.D.; Cock, M.J.W.; Julien, M.H. Biological Control of Weeds: A World Catalogue of Agents and Their Target Weeds, 5th ed.; USDA Forest Service, Forest Health Technology Enterprise Team: Morgantown, WV, USA, 2014

29. APHIS-USDA Technical Advisory Group for Biological Control Agents of Weeds TAG Petitions-APHIS Actions 2021. Available online: https:/ / www.aphis.usda.gov/plant_health/permits/tag/downloads/TAGPetitionAction.pdf (accessed on 22 January 2021).

30. Weyl, P.; Vidović, B.; Petanović, R.; Marini, F.; Cristofaro, M. Biological Control of Russian Olive, Elaeagnus Angustifolia. Annual Report 2020; CABI-CH: Delémont, Switzerland, 2021.

31. Marini, F.; Vidović, B.; Lonis, S.; Wibawa, M.I.; de Lillo, E.; Kashefi, J.; Cristofaro, M.; Smith, L. Comparison of the performance of an eriophyid mite, Aceria salsolae, on nontarget plants in the laboratory and in the field. Biol. Control 2021, 152, 104455. [CrossRef]

32. Council Horizons Regional HSNO Application Register I EPA I Release a Leaf-Galling Mite, Aceria vitalbae, as a Biological Control Agent for Old Man's Beard (Clematis vitalba). Application Code: APP203313 2021. Available online: https://www.epa.govt.nz/ database-search/hsno-application-register/view/APP203313 (accessed on 31 May 2021).

33. Smith, L.; Cartier, A.; (Manaaki Whenua Landcare Research, Lincoln, New Zealand). Personal communication, 2021.

34. Varia, S.; Wood, S.; Pratt, C.; Adair, R.; Murphy, S. A "mitey" solution to Australian swamp stonecrop. In Proceedings of the XV International Symposium on Biological Control of Weeds, Engelberg, Switzerland, 26-31 August 2018; Hinz, H., Bon, M.C., Bourdôt, G., Cristofaro, M., Desurmont, G., Kurose, D., Müller-Schärer, H., Rafter, M., Schaffner, U., Seier, M., et al., Eds.; FHAAST-2018-06. 2019; pp. 242-243.

35. Varia, S.; (CABI, Egham, UK). Personal communication, 2021.

36. Paterson, I.; Sutton, G.; Muskett, P.; Paynter, Q. Application to Introduce Paradibolia coerulea for Biological Control of Spathodea campanulata (African Tulip Tree) in the Cook Islands; Cook Islands Ministry of Agriculture: Ara Tapu, Arorangi District, Cook Islands, 2019.

37. Yeates, D.K.; Seago, A.; Nelson, L.; Cameron, S.L.; Joseph, L.; Trueman, J.W.H. Integrative taxonomy, or iterative taxonomy? Syst. Entomol. 2011, 36, 209-217. [CrossRef]

38. Magalhães, S.; Forbes, M.R.; Skoracka, A.; Osakabe, M.; Chevillon, C.; McCoy, K.D. Host race formation in the Acari. Exp. Appl. Acarol. 2007, 42, 225-238. [CrossRef] 
39. Sabelis, M.W.; Bruin, J. 1.5.3 Evolutionary ecology: Life history patterns, food plant choice and dispersal. In Eriophyoid Mites Their Biology, Natural Enemies and Control; Lindquist, E.E., Sabelis, M.W., Bruin, J., Eds.; Elsevier Science Publishing: Amsterdam, The Netherlands, 1996; Volume 6, pp. 329-366.

40. Navajas, M.; Navia, D. DNA-based methods for eriophyoid mite studies: Review, critical aspects, prospects and challenges. In Eriophyoid Mites: Progress and Prognoses; Ueckermann, E.A., Ed.; Springer: Dordrecht, The Netherlands, 2009; pp. $257-271$.

41. Petanović, R. Toward an integrative approach to taxonomy of Eriophyoidea (Acari, Prostigmata)—An overview. Ecol. Montenegrina 2016, 7, 580-599. [CrossRef]

42. Cvrković, T.; Chetverikov, P.E.; Vidović, B.; Petanović, R. Cryptic speciation within Phytoptus avellanae s.l. (Eriophyoidea: Phytoptidae) revealed by molecular data and observations on molting Tegonotus-like nymphs. Exp. Appl. Acarol. 2016, 68, 83-96. [CrossRef] [PubMed]

43. Skoracka, A. Description of Abacarus lolii n. sp. (Prostigmata: Eriophyoidea: Eriophyidae), a cryptic species within a grass-feeding Abacarus complex. Int. J. Acarol. 2009, 35, 405-417. [CrossRef]

44. Skoracka, A.; Kuczyński, L.; Santos de Mendonça, R.; Dabert, M.; Szydło, W.; Knihinicki, D.; Truol, G.; Navia, D. Cryptic species within the wheat curl mite Aceria tosichella (Keifer) (Acari: Eriophyoidea), revealed by mitochondrial, nuclear and morphometric data. Invertebr. Syst. 2012, 26, 417-433. [CrossRef]

45. Vidović, B.; Cvrković, T.; Marić, I.; Chetverikov, P.E.; Cristofaro, M.; Rector, B.G.; Petanović, R. A new Metaculus species (Acari: Eriophyoidea) on Diplotaxis tenuifolia (Brassicaceae) from Serbia: A combined description using morphology and DNA barcode data. Ann. Entomol. Soc. Am. 2015, 108, 922-931. [CrossRef]

46. Vidović, B.; Cvrković, T.; Rančić, D.; Marinković, S.; Cristofaro, M.; Schaffner, U.; Petanović, R. Eriophyid mite Aceria artemisiifoliae sp. nov. (Acari: Eriophyoidea) potential biological control agent of invasive common ragweed, Ambrosia artemisiifolia $\mathrm{L}$. (Asteraceae) in Serbia. Syst. Appl. Acarol. 2016, 21, 919-935. [CrossRef]

47. Skoracka, A.; Kuczyński, L.; Magowski, W. Morphological variation in different host populations of Abacarus hystrix (Acari: Prostigmata: Eriophyoidea). Exp. Appl. Acarol. 2002, 26, 187-193. [CrossRef]

48. Magud, B.; Stanisavljević, L.; Petanović, R. Morphological variation in different populations of Aceria anthocoptes (Acari: Eriophyoidea) associated with the Canada thistle, Cirsium arvense, in Serbia. Exp. Appl. Acarol. 2007, 42, 173-183. [CrossRef]

49. Navia, D.; de Moraes, G.J.; Querino, R.B. Geographic variation in the coconut mite, Aceria guerreronis Keifer (Acari: Eriophyidae): A geometric morphometric analysis. Int. J. Acarol. 2006, 32, 301-314. [CrossRef]

50. Skoracka, A.; Kuczyński, L. Infestation parameters and morphological variation of the wheat curl mite Aceria tosichella Keifer (Acari: Eriophyoidea). In Proceedings of the Advances in Polish Acarology; Naukowa, R., Gabrys, G., Ignatowicz, S., Eds.; Wydawnictwo SGGW: Warszawa, Poland, 2006; pp. 330-339.

51. Vidović, B.; Jojić, V.; Marić, I.; Marinković, S.; Hansen, R.; Petanović, R. Geometric morphometric study of geographic and host-related variability in Aceria spp. (Acari: Eriophyoidea) inhabiting Cirsium spp. (Asteraceae). Exp. Appl. Acarol. 2014, 64, 321-335. [CrossRef]

52. Živković, Z.; Vidović, B.; Jojić, V.; Cvrković, T.; Petanović, R. Phenetic and phylogenetic relationships among Aceria spp. (Acari: Eriophyoidea) inhabiting species within the family Brassicaceae in Serbia. Exp. Appl. Acarol. 2017, 71, 329-343. [CrossRef]

53. Duarte, M.E.; de Mendonça, R.S.; Skoracka, A.; Silva, E.S.; Navia, D. Integrative taxonomy of Abacarus mites (Eriophyidae) associated with hybrid sugarcane plants, including description of a new species. Exp. Appl. Acarol. 2019, 78, 373-401. [CrossRef]

54. Navia, D.; Gondim, M.G.C.; Aratchige, N.S.; de Moraes, G.J. A review of the status of the coconut mite, Aceria guerreronis (Acari: Eriophyidae), a major tropical mite pest. Exp. Appl. Acarol. 2013, 59, 67-94. [CrossRef]

55. Vidović, B. Taxonomic Characterization of Aceria spp. (Acari: Prostigmata: Eriophyoidea) Associated with Plant Species from the Tribe Cardueae Cass. (Asteraceae). Ph.D. Thesis, University of Belgrade, Belgrade, Serbia, 2011.

56. Živković, Z. Taxonomic Characterization of Aceria spp. (Acari: Prostigmata: Eriophyoidea) Parasites of Plant Species from the Family Brassicaceae. Ph.D. Thesis, University of Belgrade, Belgrade, Serbia, 2017.

57. de Lillo, E.; Vidović, B.; Petanović, R.; Cristofaro, M.; Marini, F.; Augé, M.; Cvrković, T.; Babić, E.; Mattia, C.; Lotfollahi, P.; et al. A new Aculodes species (Prostigmata: Eriophyoidea: Eriophyidae) associated with medusahead, Taeniatherum caput-medusae (L.) Nevski (Poaceae). Syst. Appl. Acarol. 2018, 23, 1217-1226. [CrossRef]

58. Anđelković, N.; Rector, B.G.; Marini, F.; Cristofaro, M.; Cvrković, T.; Jojić, V.; de Lillo, E.; Petanović, R.; Vidović, B. Morphological and molecular characterization of eriophyid mites Aculodes sp. on Taeniatherum caput-medusae and Bromus tectorum (Poaceae). In Proceedings of the VIII Congress on Plant Protection: "Integrated Plant Protection for Sustainable Crop Production and Forestry", Zlatibor, Serbia, 25-29 November 2019; p. 166.

59. Carmona, M.M. Metaculus rapistri n. sp. (Acarina: Eriophyoidea) from Portugal. Agron. Lusit. 1969, 30, 89-92.

60. Monfreda, R.; de Lillo, E. Eriophyoid mites (Acari: Eriophyoidea) on Brassicaceae: A new species of Metaculus from Turkey and remarks on other species associated with brassicaceous plants. Zootaxa 2012, 3154, 47. [CrossRef]

61. Marini, F.; Weyl, P.; Cristofaro, M.; De Lillo, E.; Vidović, B.; Petanović, R. The integrative taxonomy in classic biological control of weeds: Metaculus sp. on Isatis tinctoria a case of study. In Proceedings of the XV International Symposium on Biological Control of Weeds, Engelberg, Switzerland, 26-31 August 2018; Hinz, H., Bon, M.C., Bourdôt, G., Cristofaro, M., Desurmont, G., Kurose, D., Müller-Schärer, H., Rafter, M., Schaffner, U., Seier, M., et al., Eds.; FHAAST-2018-06. 2019; p. 143. 
62. Vidović, B.; Weyl, P.; Marini, F.; Cristofaro, M.; Cvrković, T.; Jojić, V.; Petanović, R. Morphological and molecular characterization of Metaculus eriophyid mites from Rapistrum rugosum and Isatis tinctoria (Brassicaceae). In Proceedings of the VIII Congress on Plant Protection: "Integrated Plant Protection for Sustainable Crop Production and Forestry", Zlatibor, Serbia, 25-29 November 2019; p. 165.

63. Vidović, B.; Petanović, R.; Crković, T.; Marinković, S.; Cristofaro, M.; Schaffner, U. Morphological and molecular characterization of eriophyid mites on Russian olive, Elaeagnus angustifolia L. In Proceedings of the VIII Congress on Plant Protection: “Integrated Plant Protection for Sustainable Crop Production and Forestry", Zlatibor, Serbia, 25-29 November 2019; pp. $218-219$.

64. Kovalev, O.V.; Shevchenko, V.G.; Danilov, L.G. Aceria acroptiloni, sp. n. (Acarina, Tetrapodili), a promising phytophage for the biological control of Russian knapweed. Entomol. Rev. 1974, 53, 280-290.

65. Chetverikov, P.E.; Cristofaro, M.; de Lillo, E.; Petanović, R.; Shaffner, U.; Vidović, B. New taxonomical data on Aceria acroptiloni (Acari, Eriophyoidea), a potential biological control agent of the weed Acroptilon repens. In Proceedings of the II International Conference to Commemorate Prof M.A. Kozlov "Modern Zoological Studies in Russia and Adjacent"; Dimitriev, A.V., Egorov, L.V., Sinichkin, E.A., Eds.; Novoye vremya Press: Cheboksary, Russia, 2012; pp. 145-146.

66. de Lillo, E.; Panzarino, O.; Loverre, P.; Valenzano, D.; Mattia, C.; Marini, F.; Augé, M.; Cristofaro, M. New eriophyoid mites from Italy. IV. Mites associated with weed plants. Syst. Appl. Acarol. 2017, 22, 2256-2272. [CrossRef]

67. Cristofaro, M.; de Lillo, E. La pianta Ailanthus altissima e studio della fattibilità di un programma di controllo biologico. Atti Accad. Naz. Ital. Entomol. 2019, Anno LXVII, 73-79.

68. Skvarla, M.J.; Ochoa, R.; Ulsamer, A.; Amrine, J.W. The eriophyid mite Aculops ailanthi Lin, Jin, Kuang, 1997 (Acariformes: Prostigmata: Eriophyidae) from tree-of-heaven in the United States-New state records and morphological observations. Acarologia 2021, 61, 121-127. [CrossRef]

69. de Lillo, E.; Craemer, C.; Amrine, J.W.; Nuzzaci, G. Recommended procedures and techniques for morphological studies of Eriophyoidea (Acari: Prostigmata). Exp. Appl. Acarol. 2010, 51, 283-307. [CrossRef]

70. Bijani, F.; Naderi, R.; Akrami, A.M.; Weyl, P.; Heidari, B.; Edalat, M. Impact of Aceria alhagi (Acari: Eriophyidae) as a potential biological control agent on the invasive weed Alhagi maurorum (Fabaceae) in its native range. Exp. Appl. Acarol. 2021. [CrossRef]

71. Vidović, B.; Kamali, H.; Petanović, R.; Cristofaro, M.; Weyl, P.; Ghorbanali, A.; Cvrković, T.; Augé, M.; Marini, F. A new Aceria species (Acari: Trombidiformes: Eriophyoidea) from west Asia, a potential biological control agent for the invasive weed camelthorn, Alhagi maurorum Medik. (Leguminosae). Acarologia 2018, 58, 302-312. [CrossRef]

72. Skoracka, A.; Dabert, M. The cereal rust mite Abacarus hystrix (Acari: Eriophyoidea) is a complex of species: Evidence from mitochondrial and nuclear DNA sequences. Bull. Entomol. Res. 2010, 100, 263-272. [CrossRef] [PubMed]

73. Chetverikov, P.E.; Klimov, P.; Letukhova, V.Y.; Ripka, G.; Zukoff, S. Two new phyllocoptine species and new records of eriophyoid mites (Eriophyidae, Phyllocoptinae) from Crimea, with evaluation of the phylogenetic position of the new taxa using GenBank data. Syst. Appl. Acarol. 2019, 24, 882-904. [CrossRef]

74. Laska, A.; Majer, A.; Szydło, W.; Karpicka-Ignatowska, K.; Hornyák, M.; Labrzycka, A.; Skoracka, A. Cryptic diversity within grass-associated Abacarus species complex (Acariformes: Eriophyidae), with the description of a new species, Abacarus plumiger $\mathrm{n}$. sp. Exp. Appl. Acarol. 2018, 76, 1-28. [CrossRef]

75. Szydło, W.; Hein, G.; Denizhan, E.; Skoracka, A. Exceptionally high levels of genetic diversity in wheat curl mite (Acari: Eriophyidae) populations from Turkey. J. Econ. Entomol. 2015, 108, 2030-2039. [CrossRef]

76. Skoracka, A.; Kuczyński, L. Measuring the host specificity of plant-feeding mites based on field data-A case study of the Aceria species. Biologia 2012, 67, 546-560. [CrossRef]

77. Skoracka, A.; Kuczyński, L.; Szydło, W.; Rector, B.G. The wheat curl mite Aceria tosichella (Acari: Eriophyoidea) is a complex of cryptic lineages with divergent host ranges: Evidence from molecular and plant bioassay data. Biol. J. Linn. Soc. 2013, 109, 165-180. [CrossRef]

78. Stalažs, A.; Moročko-Bičevska, I. Species identification, host range and diversity of Cecidophyopsis mites (Acari: Trombidiformes) infesting Ribes in Latvia. Exp. Appl. Acarol. 2016, 69, 129-153. [CrossRef]

79. Kaushik, D.; Srivastava, S.; Singh, J.P.; Chauhan, V.B.; Singh, R.N. Evaluation of pigeonpea genotypes against Sterility Mosaic Disease (SMD) caused by the mite vector, Aceria cajani. J. Mycopathol. Res. 2013, 51, 225-233.

80. Schaffner, U. Host range testing of insects for biological weed control: How can it be better interpreted? Bioscience 2001, 51, 951-959. [CrossRef]

81. Clement, S.; Cristofaro, M. Open-field tests in host-specificity determination of insects for biological control of weeds. Biocontrol Sci. Technol. 1995, 5, 395-406. [CrossRef]

82. Schaffner, U.; Smith, L.; Cristofaro, M. A review of open-field host range testing to evaluate non-target use by herbivorous biological control candidates. BioControl 2018, 63, 405-416. [CrossRef]

83. Bergh, J.C. Ecology and aerobiology of dispersing citrus rust mites (Acari: Eriophyidae) in central Florida. Environ. Entomol. 2001, 30, 318-326. [CrossRef]

84. Bergh, J.C.; McCoy, C.W. Aerial dispersal of citrus rust mite (Acari: Eriophyidae) from Florida citrus groves. Environ. Entomol. 1997, 26, 256-264. [CrossRef]

85. Nault, L.R.; Styer, W.E. The dispersal of Aceria tulipae and three other grass-infesting eriophyid mites in Ohio. Ann. Entomol. Soc. Am. 1969, 62, 1446-1455. [CrossRef] 
86. Zhao, S.; Amrine, J.W. A new method for studying aerial dispersal behaviour of eriophyoid mites (Acari: Eriophyoidea). Syst. Appl. Acarol. 1997, 2, 107-110. [CrossRef]

87. Hinz, H.L.; Schwarzländer, M.; Gassmann, A.; Bourchier, R.S. Successes we may not have had: A retrospective analysis of selected weed biological control agents in the United States. Invasive Plant Sci. Manag. 2014, 7, 565-579. [CrossRef]

88. Stoeva, A.; Harizanova, V.; de Lillo, E.; Cristofaro, M.; Smith, L. Laboratory and field experimental evaluation of host plant specificity of Aceria solstitialis, a prospective biological control agent of yellow starthistle. Exp. Appl. Acarol. 2012, 56, 43-55. [CrossRef]

89. Smith, L. Host plant specificity and potential impact of Aceria salsolae (Acari: Eriophyidae), an agent proposed for biological control of Russian thistle (Salsola tragus). Biol. Control 2005, 34, 83-92. [CrossRef]

90. Smith, L.; Cristofaro, M.; de Lillo, E.; Monfreda, R.; Paolini, A. Field assessment of host plant specificity and potential effectiveness of a prospective biological control agent, Aceria salsolae, of Russian thistle, Salsola tragus. Biol. Control 2009, 48, 237-243. [CrossRef]

91. Channabasavanna, G.P.; Nangia, N. The biology of gall mites. In Biology of Gall Insects; Ananthakrishnan, T.N., Ed.; Edward Arnold Publisher: London, UK, 1984; pp. 323-337. ISBN 0-7131-2906-9.

92. Valenzano, D.; Bari, G.; Malagnini, V.; de Lillo, E. Off-host survival of Eriophyoidea and remarks on their dispersal modes. Exp. Appl. Acarol. 2019, 79, 21-33. [CrossRef] [PubMed]

93. Skoracka, A.; Kuczyński, L.; Rector, B.G.; Amrine, J.W. Wheat curl mite and dry bulb mite: Untangling a taxonomic conundrum through a multidisciplinary approach. Biol. J. Linn. Soc. 2014, 111, 421-436. [CrossRef]

94. Salome, M.; Rosario, D.E.; Sill, J.W.H. Additional biological and ecological characteristics of Aceria tulipae (Acarina: Eriophyidae). J. Econ. Entomol. 1964, 57, 893-896. [CrossRef]

95. Jeppson, L.R.; Keifer, H.H.; Baker, E.W. Mites Injurious to Economic Plants; University of California Press: Berkeley, CA, USA, 1975; ISBN 9780520335431.

96. Kiedrowicz, A.; Kuczyński, L.; Lewandowski, M.; Proctor, H.; Skoracka, A. Behavioural responses to potential dispersal cues in two economically important species of cereal-feeding eriophyid mites. Sci. Rep. 2017, 7, 3890. [CrossRef]

97. Weyl, P.; Schaffner, U.; Asadi, G.A.; Sànchez-Alcocer, T.; Vidović, B.; Petanović, R.; Marini, F.; Cristofaro, M. Biological Control of Russian Knapweed, Rhaponticum Repens. Annual Report 2017; CABI-CH: Delémont, Switzerland, 2018.

98. McClay, A.S.; Balciunas, J.K. The role of pre-release efficacy assessment in selecting classical biological control agents for weeds-applying the Anna Karenina principle. Biol. Control 2005, 35, 197-207. [CrossRef]

99. Willis, A.J.; Berentson, P.R.; Ash, J.E. Impacts of a weed biocontrol agent on recovery from water stress in a target and a non-target Hypericum species. J. Appl. Ecol. 2003, 40, 320-333. [CrossRef]

100. Craemer, C. Host specificity, and release in South Africa, of Aceria malherbae Nuzzaci (Acari: Eriophyoidea), a natural enemy of Convolvulus arvensis L. (Convolvulaceae). African Entomol. 1995, 3, 213-222.

101. McClay, A.S.; De Clerck-Floate, R.A. Convolvulus arvensis L., field bindweed (Convolvulaceae). In Biological Control Programmes in Canada, 1981-2000; Mason, P.G., Huber, J.T., Eds.; CABI Publishing: Wallingford, UK, 2002; pp. 331-337. ISBN 978-0-85199-527-4.

102. Clement, S.L.; Rosenthal, S.S.; Mimmocchi, T.; Cristofaro, M.; Nuzzaci, G. Concern for US native plants affects biological control of field bindweed. In Proceedings of the 10th International Congress of Plant Protection, Brighton, UK, 20-25 November 1983; British Crop Protection Council: Croydon, UK, 1983; Volume 2.

103. Rosenthal, S.S.; Platts, B.E. Host specificity of Aceria (Eriophyes) malherbe, [Acari: Eriophyidae], a biological control agent for the weed, Convolvulus arvensis [Convolvulaceae]. Entomophaga 1990, 35, 459-463. [CrossRef]

104. Hufbauer, R.A.; Roderick, G.K. Microevolution in biological control: Mechanisms, patterns, and processes. Biol. Control 2005, 35, 227-239. [CrossRef]

105. Skoracka, A. Host specificity of eriophyoid mites: Specialists or generalists? Biol. Lett. 2006, 43, $289-298$.

106. Caresche, L.A.; Wapshere, A.J. Biology and host specificity of the Chondrilla gall mite Aceria chondrillae (G. Can.) (Acarina, Eriophyidae). Bull. Entomol. Res. 1974, 64, 183-192. [CrossRef]

107. Sobhian, R.; Andres, L.A. The response of the skeletonweed gall midge, Cystiphora schmidti (Diptera: Cecidomyiidae), and gall mite, Aceria chondrillae (Eriophyidae) to North American strains of rush skeletonweed (Chondrilla juncea). Environ. Entomol. 1978, 7, 506-508. [CrossRef]

108. Cullen, J.M.; Moore, D. The influence of three populations of Aceria chondrillae on three forms of Chondrilla juncea. J. Appl. Ecol. 1983, 20, 235-243. [CrossRef]

109. Goolsby, J.A.; De Barro, P.J.; Makinson, J.R.; Pemberton, R.W.; Hartley, D.M.; Frohlich, D.R. Matching the origin of an invasive weed for selection of a herbivore haplotype for a biological control programme. Mol. Ecol. 2005, 15, 287-297. [CrossRef] [PubMed]

110. Cristofaro, M.; Roselli, G.; Marini, F.; de Lillo, E.; Petanović, R.; Vidović, B.; Augé, M.; Rector, B.G. Open field evaluation of Aculodes altamurgensis, a recently described eriophyid species associated with medusahead (Taeniatherum caput-medusae). Biocontrol Sci. Technol. 2020, 30, 339-350. [CrossRef]

111. Mukwevho, L.; Olckers, T.; Simelane, D.O. Establishment, dispersal and impact of the flower-galling mite Aceria lantanae (Acari: Trombidiformes: Eriophyidae) on Lantana camara (Verbenaceae) in South Africa. Biol. Control 2017, 107, 33-40. [CrossRef]

112. Mukwevho, L.; Simelane, D.O.; Olckers, T. Host-plant variety and not climate determines the establishment and performance of Aceria lantanae (Eriophyidae), a biological control agent of Lantana camara in South Africa. Exp. Appl. Acarol. 2017, 71, 103-113. [CrossRef] 
113. Briese, D.T.; Cullen, J.M. The use and usefulness of mites in biological control of weeds. In Proceedings of the Acarology: Proceedings of the 10th International Congress, Canberra, Australia, 5-10 July 1998; Halliday, R.B., Walter, D.E., Proctor, H.C., Norton, R.A., Colloff, M.J., Eds.; CSIRO Publishing: Collingwood, VIC, Australia, 2001; pp. 453-463.

114. Sheppard, A.W. Prioritising agents based on predicted efficacy: Beyond the lottery approach. Tech. Ser. CRC Aust. Weed Manag. 2003, 7, 11-21.

115. Harms, N.E.; Cronin, J.T.; Diaz, R.; Winston, R.L. A review of the causes and consequences of geographical variability in weed biological control successes. Biol. Control 2020, 151, 104398. [CrossRef]

116. Schaffner, U.; Hill, M.; Dudley, T.; D’Antonio, C. Post-release monitoring in classical biological control of weeds: Assessing impact and testing pre-release hypotheses. Curr. Opin. Insect Sci. 2020, 38, 99-106. [CrossRef] [PubMed]

117. Boydston, R.A.; Williams, M.M. Combined effects of Aceria malherbae and herbicides on field bindweed (Convolvulus arvensis) growth. Weed Sci. 2004, 52, 297-301. [CrossRef]

118. Littlefield, J.L. Spatial distribution and seasonal life history of Aceria malherbae (Acari: Eriophyidae) on Convolvulus arvensis in Montana, USA. In Proceedings of the XI International Symposium on Biological Control of Weeds, Canberra, Australia, 27 April-2 May 2003; Cullen, J.M., Briese, D.T., Kriticos, D.J., Lonsdale, W.M., Morin, L., Scott, J.K., Eds.; CSIRO Publishing: Canberra, ACT, Australia, 2004; p. 607.

119. Konigsberg, E.R. Factors Involved in the Success and Establishment of the Field Bindweed Gall Mite Aceria malherbae Nuzzaci (Acari: Eriophyidae). Master's Thesis, Montana State University, Bozeman, MT, USA, 2014.

120. Mukwevho, L.; Mphephu, T.E. The role of the flower-galling mite, Aceria lantanae, in integrated control of the light pink $163 \mathrm{LP}$ variety of Lantana camara (L.) in South Africa. Biol. Control 2020, 149, 104309. [CrossRef]

121. Weyl, P.; Asadi, G.A.; Cristofaro, M.; Vidović, B.; Petanović, R.; Marini, F.; Schaffner, U. The host range and impact of Aceria angustifoliae (Eriophyidae), a potential biological control agent against Russian olive, Elaeagnus angustifoliae (Elaeagnaceae) in North America. Biocontrol Sci. Technol. 2020, 30, 85-92. [CrossRef]

122. Asadi, G.A.; Ghorbani, R.; Cristofaro, M.; Chetverikov, P.E.; Petanović, R.; Vidović, B.; Schaffner, U. The impact of the flower mite Aceria acroptiloni on the invasive plant Russian knapweed, Rhaponticum repens, in its native range. BioControl 2014, 59, 367-375. [CrossRef]

123. Goolsby, J.A.; Zonneveld, R.; Bourne, A. Prerelease assessment of impact on biomass production of an invasive weed, Lygodium microphyllum (Lygodiaceae: Pteridophyta), by a potential biological control agent, Floracarus perrepae (Acariformes: Eriophyidae). Environ. Entomol. 2004, 33, 997-1002. [CrossRef]

124. Weyl, P.; Closça, C.; Asadi, G.A.; Vidović, B.; Petanović, R.; Marini, F.; Cristofaro, M. Biological Control of Russian Knapweed, Rhaponticum Repens. Annual Report 2019; CABI-CH: Delémont, Switzerland, 2020.

125. Boughton, A.J.; Pemberton, R.W. Limited field establishment of a weed biocontrol agent, Floracarus perrepae (Acariformes: Eriophyidae), against Old World climbing fern in Florida-A possible role of mite resistant plant genotypes. Environ. Entomol. 2011, 40, 1448-1457. [CrossRef] [PubMed]

126. David, A.S.; Jones, I.M.; Lake, E.C. Wind speed predicts population dynamics of the eriophyid mite Floracarus perrepae on invasive Old World climbing fern (Lygodium microphyllum) in a shade house colony. Exp. Appl. Acarol. 2019, 78, 263-272. [CrossRef]

127. David, A.S.; Lake, E.C. Eriophyid mite Floracarus perrepae reduces climbing ability of the invasive vine Lygodium microphyllum. Biol. Control 2020, 146. [CrossRef]

128. Hansen, R. Handling insects for use as terrestrial biological control agents. In Biological Control of Invasive Plants in the United States; Combs, E.M., Clark, J.K., Piper, G.L., Cofrancesco, A.F., Eds.; Oregon State University Press: Corvallis, OR, USA, 2004; pp. $59-70$.

129. Silvestri, L.; Sosa, A.; Mc Kay, F.; Vitorino, M.D.; Hill, M.; Zachariades, C.; Hight, S.; Weyl, P.; Smith, D.; Djeddour, D.; et al. Implementation of access and benefit-sharing measures has consequences for classical biological control of weeds. BioControl 2020, 65, 125-141. [CrossRef]

130. Morin, L. Progress in biological control of weeds with plant pathogens. Annu. Rev. Phytopathol. 2020, 58, 201-223. [CrossRef]

131. Stutz, S.; Nikolova, E.; Hinz, H.L.; Cristofaro, M.; Augé, M.; Marini, F.; Di Cristina, F.; Yu, M.; Dolgovskaya, M.; Volkovitch, M.; et al. Biological Control of Perennial Pepperweed, Lepidium latifolium. Annual Report 2016; CABI-CH: Delémont, Switzerland, 2017.

132. Weyl, P.; Closça, C.; Asadi, G.A.; Vidović, B.; Petanović, R.; Marini, F.; Cristofaro, M. Biological Control of Russian Olive, Elaeagnus Angustifolia. Annual Report 2018; CABI-CH: Delémont, Switzerland, 2019.

133. Bruckart, W.L.; Berned, D.K.; Caesar, A.J.; Widmer, T.L. Plant pathology and biological control of invasive weeds. In Biological Control of Invasive Plants in the United States; Combs, E.M., Clark, J.K., Piper, G.L., Cofrancesco, A.F., Eds.; Oregon State University Press: Corvallis, OR, USA, 2004; pp. 50-58.

134. Bean, D.; (Colorado Department of Agriculture, Palisade, CO, USA). Personal communication, 2021.

135. Ozman, S.K.; Goolsby, J.A. Biology and phenology of the eriophyid mite, Floracarus perrepae, on its native host in Australia, Old World climbing fern, Lygodium microphyllum. Exp. Appl. Acarol. 2005, 35, 197-213. [CrossRef]

136. Ma, M.; Fan, Q.-H.; Zhang, Z.-Q. An assemblage of predatory mites (Phytoseiidae) associated with a potential biocontrol agent (Cecidophyes rouhollahi; Eriophyidae) for weed Galium spurium (Rubiaceae). Syst. Appl. Acarol. 2018, 23, 2082-2085. [CrossRef]

137. McCoy, C. 2.4 Pathogens of eriophyoid mites. In Eriophyoid Mites Their Biology, Natural Enemies and Control; Lindquist, E.E., Sabelis, M.W., Bruin, J., Eds.; Elsevier Science Publishing: Amsterdam, The Netherlands, 1996; Volume 6, pp. 481-490. 
138. Sabelis, M.W. 2.1 Phytoseiidae. In Eriophyoid Mites Their Biology, Natural Enemies and Control; Lindquist, E.E., Sabelis, M.W., Bruin, J., Eds.; Elsevier Science Publishing: Amsterdam, The Netherlands, 1996; Volume 6, pp. 427-456.

139. Xue, X.-F.; Han, X.; Zhang, Z.-Q. Correct identification and biosecurity decision-making: Two species instead of one in Aceria genistae complex (Acari: Eriophyidae) in New Zealand. Syst. Appl. Acarol. 2015, 20, 71-86. [CrossRef]

140. Oldfield, G.; Proeseler, G. 1.4.9 Eriophyoid mites a vectors of plant pathogens. In Eriophyoid Mites Their Biology, Natural Enemies and Control; Lindquist, E.E., Sabelis, M.W., Bruin, J., Eds.; Elsevier Science Publishing: Amsterdam, The Netherlands, 1996; Volume 6, pp. 259-275.

141. Sobhian, R.; McClay, A.; Hasan, S.; Peterschmitt, M.; Hughes, R.B. Safety assessment and potential of Cecidophyes rouhollahi (Acari, Eriophyidae) for biological control of Galium spurium (Rubiaceae) in North America. J. Appl. Entomol. 2004, 128, 258-266. [CrossRef]

142. McClay, A. Field Evaluation of a Gall Mite for Biological Control of False Cleavers; McClay Ecoscience: Sherwood Park, AB, Canada, 2005.

143. Boldt, P.E.; Sobhian, R. Release and establishment of Aceria malherbae (Acari: Eriophyidae) for control of field bindweed in Texas. Environ. Entomol. 1993, 22, 234-237. [CrossRef]

144. McClay, A.S.; Littlefield, J.L.; Kashefi, J. Establishment of Aceria malherbae (Acari: Eriophyidae) as a biological control agent for field bindweed (Convolvulaceae) in the Northern Great Plains. Can. Entomol. 1999, 131, 541-547. [CrossRef]

145. Sagliocco, J.; Sheppard, A.; Hosking, J.; Hodge, P.; Paynter, Q.; Gourlay, H.; Ireson, J.J. Host specificity testing, release and successful establishment of the broom gall mite (Aceria genistae) in Australia and New Zealand for the biological control of broom (Cytisus scoparius). In Proceedings of the XIII International Symposium on Biological Control of Weeds, Waikoloa Beach, HI, USA, 11-16 September 2011; Wu, Y., Johnson, T., Sing, S., Raghu, S., Wheeler, G., Pratt, P., Warner, K., Center, T., Goolsby, J.A., Reardon, R., Eds.; U.S. Forest Service, Pacific Southwest Research Station, Institute of Pacific Islands Forestry: Hilo, HI, USA, 2013; Volume FHTET-201, pp. 409-416.

146. Paynter, Q.; Fowler, S.V.; Gourlay, A.H.; Peterson, P.G.; Smith, L.A.; Winks, C.J. The influence of agent rearing success and release size on weed biocontrol programs in New Zealand. Biol. Control 2016, 10, 187-193. [CrossRef]

147. Rodríguez-Navarro, S.; Rodríguez Morell, H.; Martínez, J.G.; Flores-Macías, A.; Torres-Martínez, J. Valuation of quality parameters for rearing Aceria malherbae Nuzzaci (Acari: Eriophyidae), a biological control agent of field bindweed, Convolvulus arvensis L. Int. J. Acarol. 2011, 37, 235-243. [CrossRef]

148. Rodríguez-Navarro, S.; Flores-Macías, A.; Torres-Martínez, G. Evaluation of infesting field bindweed (Convolvulus arvensis L.) with Aceria malherbae Nuzzaci (Acari: Eriophyidae) under glasshouse conditions. Int. J. Acarol. 2008, 34, 151-154. [CrossRef]

149. Leppla, N. Principles of quality control in mass-reared arthropods. In Proceedings of the Seventh Workshop of the IOBC Global Working Group “Quality Control of Mass Reared Arthropods”, Rimini, Italy, 13-16 September 1993; Nicoli, G., Benuzzi, M., Leppla, N.C., Eds.; IOBC: Rimini, Italy, 1993; pp. 1-11.

150. van Lenteren, J.C. Need for quality control of mass produced biological agents. In Quality Control and Production of Biological Control Agents-Theory and Testing Procedures; van Lenteren, J.C., Ed.; CABI: Wallingford, UK, 2003; pp. 1-18. ISBN 978-0-85199-688-2.

151. Friend, E.; Kelly, J.; Friend, C.; Peeper, T.; Gles, K.; Royer, T. Biological Control of Field Bindweed in Oklahoma; Department of Plant and Soil Sciences, Oklahoma State University: Stillwater, OK, USA, 2002.

152. Littlefield, J.L. Biological control of field bindweed survey. In Montana Department of Agriculture Pest Survey Reports 2007; Denke, P., Mettler, M., Merenz, M., Eds.; Montana State Univeristy: Bozeman, MT, USA, 2007; p. 51.

153. Pratt, P.D.; Pitcairn, M.J.; Oneto, S.; Kelley, M.B.; Sodergren, C.J.; Beaulieu, F.; Knee, W.; Andreas, J. Invasion of the gall mite Aceria genistae (Acari: Eriophyidae), a natural enemy of the invasive weed Cytisus scoparius, into California, U.S.A. and predictions for climate suitability in other regions using ecological niche modelling. Biocontrol Sci. Technol. 2019, 29, 494-513. [CrossRef]

154. Blossey, B.; Skinner, L. Design and importance of post-release monitoring. In Proceedings of the X International Symposium on Biological Control of Weeds, Montana State University, Bozeman, MT, USA, 4-14 July 1999; Spencer, N.R., Ed.; Montana State Univeristy: Bozeman, MT, USA, 2000; pp. 693-706.

155. Blossey, B. Monitoring in weed biological control programs. In Biological Control of Invasive Plants in the United States; Combs, E.M., Clark, J.K., Piper, G.L., Cofrancesco, A.F., Eds.; Oregon State University Press: Corvallis, OR, USA, $2004 ;$ pp. 95-105.

156. Winston, R.L.; Randall, C.B.; De Clerck-Floate, R.A.; McClay, A.; Andreas, J.; Schwarzländer, M. Field Guide for the Biological Control of Weeds in Eastern North America; FHTET-2014; USDA Forest Service, Forest Health Technology Enterprise Team: Morgantown, WV, USA, 2014.

157. de Lillo, E. A modified method for eriophyoid mite extraction (Acari: Eriophyoidea). Int. J. Acarol. 2001, 27, 67-70. [CrossRef]

158. Monfreda, R.; Lekveishvili, M.; Petanović, R.; Amrine, J.W. Collection and detection of eriophyoid mites. In Eriophyoid Mites: Progress and Prognoses; Ueckermann, E.A., Ed.; Springer: Dordrecht, The Netherlands, 2010; pp. 273-282. ISBN 978-90-481-9562-6.

159. Monfreda, R.; Nuzzaci, G.; de Lillo, E. Detection, extraction, and collection of eriophyoid mites. Zootaxa 2007, 1662, 35-43. [CrossRef]

160. Perring, T.; Farrar, C.; Oldfield, G. 1.6 Sampling techniques. In Eriophyoid Mites Their Biology, Natural Enemies and Control; Lindquist, E.E., Sabelis, M.W., Bruin, J., Eds.; Elsevier Science Publishing: Amsterdam, The Netherlands, 1996; Volume 6, pp. 367-376. 